\title{
LA LEY ITALIANA DE 8 DE JUNIO DE 1990, RELATIVA AL ORDENAMIENTO DE LAS AUTONOMIAS LOCALES
}

\author{
(TRADUCCION Y NOTA INTRODUCTORIA: ANTONIO FANLO LORAS)
}

La Gazzetta Ufficiale de la República italiana publicaba, en el suplemento ordinario al número de 12 de junio de 1990, la ley 142, de 8 de junio de 1990, relativa al ordenamiento de las autonomías locales. Con su publicación se ponía punto final a la incapacidad endémica del legislador italiano para llevar a buen puerto una reforma emprendida una $y$ otra vez en cada legislatura y siempre malograda hasta ahora como consecuencia de la inestabilidad del sistema político italiano: el difícil equilibrio del "pentapartito" en el Gobierno de la Nación.

Detrás quedan, también, varios decenios de apasionado debate de la doctrina italiana ocupada en la tarea de interpretar los principios de la Constitución de 1948 en materia de autonomías locales que ha generado centenares de miles de páginas, innumerables proyectos de reforma que nunca encontraron suficiente empuje y acuerdo político para materializarse en un texto legal. A partir de ahora, la discusión ha de cobrar una orientación bien distinta puesto que la nueva ley recogen buena parte de las propuestas y soluciones organizativas formuladas por la doctrina en estos años.

La Ley de 8 de junio de 1990 pone fin a una situación legislativa considerada por todos como insostenible. Pese a que la Constitución republicana de 1948 configuró un modelo de organización territorial fundado en el principio de autonomía, continuaba vigente la legislación monárquica prefascista de inspiración centralista (textos de 1911, 1915 y sobre todo el texto único de la ley municipal y provincial de 1934), ahora derogadas formalmente, salvo preceptos aislados de cArácter técnico.

Creo innecesario hacer siquiera una escueta referencia a los numerosos proyectos de ley que han precedido al actual. Sin olvidar las propuestas provenientes del ámbito universitario (el Proyecto de Pavia de 1977, conocido como Legge generale sull'amministrazione locale, fruto de la colaboración de varios profesores de la Universidad de Pavía, dirigidos por POTOSCHING, o los dirigidos por M.S. GIANNI, Rapporto sui principali problemi dell'amministrazione dello Stato, de 1981 y el mas reciente y específico Scheme di legge sulla riforma delle autonomie locale, de 1989 (1)) han sido muy numerosos los proyectos y proposiciones de ley presentados en los últimos quince años por los partidos y gru-

(1) Publicado por la revista Regione e Governo locale, 4(1989), pp. 41-63. 
pos políticos. La Revista Regione e Governo locale ha publicado como suplemento a los números $5 / 6$ de 1988 , los diversos proyectos sobre el ordenamiento de las autonomías locales presentados en la Cámara de los Diputados y que han dado origen a la ley de 8 de junio de 1990.

Por cierto conviene advertir acerca de una cuestión meramente formal pero que debiera ser tenida en cuenta por el legislador español a la hora de publicar los textos normativos. La Gazzetta Ufficiale, junto a la publicación del texto de la ley, y en cumplimiento del texto único aprobado mediante Decreto del Presidente de la República de 28 de diciembre de 1985, incluye como Nota final el texto de las disposiciones normativas modificadas o las que se remite la nueva ley, al efecto de facilitar su lectura. Igualmente incluye una nota, con la oportuna referencia numérica, de los trabajos parlamentarios seguidos en relación con la nueva ley en la Cámara de parlamentarios seguidos en relación con la nueva ley en la Cámara de parlamentarios y en el Senado. Este último dato permite acceder cómodamente y con gran rapidez a la intrincada documentación parlamentaria que no siempre es de fácil manejo si no tienen previamente las referencias. Desde estas líneas hago un llamamiento a los servicios de documentación del Congreso y del Senado para que junto con el texto de las leyes que se aprueben. se envíe al Boletín Oficial del Estado la citada referencia de los trabajos parlamentarios, como por lo demás es práctica habitual en otros paises (caso de Francia).

Abundantísima sería la bibliografía italiana a la que remitir para comprender la problemática que aborda y resuelve la nueva ley. Baste la cita de uno de los más recientes, publicado unos meses antes de que se aprobase la ley. Me refiero al libro de Luciano VANDELLI, I poteri locali. Le originale nella Francia rivoluzionaria. Le prospettive nell'Europa delle regioni, Ed. II Mulino, Bolonia, 1990, autor que a su preocupación sostenida por los problemas del régimen local italiano une, además, un profundo conocimiento de la Administración territorial de otos paises (particularmente de Francia y España). El propio VANDELLI nos facilita la interpretación de la nueva ley con el que puede ser, en lo que conozco, el primer comentario a la misma, Ordinamento delle autonomic locale (commento alla legga 8 giugno 1990, n 142), Maggioli Editore, Rimini, 1990. En lo que se refiere a la bibliografía española considero utilísima la lectura del apretado trabajo de J. TORNOS MAS, "La reforma de la Administración italiana", publicado en la Revista de Administración Pública, núm. 112(1987), pp. 359-377. En él pueden encontrarse expuestas con gran claridad las grandes líneas de la reforma del régimen local italiana que ahora tienen su plasmación legal. 
En cuanto a los aspectos más significativos de la ley de 8 de junio de 1990, relativa al ordenamiento de las autonomías locales yo destacaría:

1) El municipio, como ente representativo de la comunidad local, continua siendo la pieza central del sistema. Se abandona la política de reforma drástica y desde arriba de la planta de la Administración local (como defendió en su dia M.S. GIANNINI) seguida por ejemplo en Inglaterra. La ley italiana sigue en ésto los pasos de la reforma francesa (1982) y española (1985) y confia que sean los propios municipios los que a través de medidas asociativas vayan creando en al presente (uniones de municipios, art. 26) la alternativa futura de una planta de la Administración local más idónea. En todo caso, se fijan unos mínimos a las regiones en su política de reestructuración municipal. No podrán crearse nuevos municipios si no cuentan con al menos 10.000 habitantes, salvo los supuestos de fusión de otros prexistentes (art 11).

2) El debate doctrinal en torno al ente intermedio (nivel supramunicipal inferior al espacio regional), traducido en la creación caótica por el Estado y por las Regiones de diferentes figuras intermedias (Unidades Sanitarias Locales, Comunidades de montaña; Comprensorios, etc.), se decanta en la ley por una recuperación de la provincia (2), cuyas funciones de programación y de gestión de determinados servicios quedan notablemente potenciadas y fortalecidas en la nueva ley (art. $14,15)$. Sin prejuicio del reconocimiento de la utilidad de otras figuras asociativas (consorcios, uniones de municipios, acuerdos de programa, comunidades montaña, áreas metropolitanas, y los circondarios) hay que destacar el papel central reservado la provincia en la nueva planta de la Administración Local italiana, facilitado además por una concepción más flexible que la española en cuanto a la alteración de los límites provinciales.

3) La nueva ley en lo relativo a la distribución de competencias entre los entes locales (municipios y provincias) ratifica el sistema introducido por el DPR 616/1977, de 24 de julio, al retribuir a los municipios las funciones relativas a los ámbitos materiales de los servicios sociales, ordenación y utilización del territorio y desarrollo económico, en cuanto no esté atribuido a otros entes por las leyes estatales o regionales (art. 9). Se parte

(2) Véase sobre la recuperación de la provincia el trabajo de J. TORNOS MAS, p. 369 y la bibliografía en el citada. 
de una concepción no compartimentalizada, sino participada de las Administraciones Públicas. En este contexto adquiere una importancia capital, como destaca TORNOS MAS en su trabajo, la "idea de programación como método de actuación" de las regiones y provincias, sobre todo, en la que tienen una importante participación los municipios.

4) La ley reconoce potestad estatutaria y reglamentaria a los municipios como expresión del principio de autonomía y autoorganización de los entes locales (art. 4 y 5), como unánimemente había reclamado la doctrina (3). Ello ha de permitir flexibilizar la rígida uniformidad que a pesado sobre la Administración Local italiana: las normas fundamentales de la organización del ente en cuanto a las atribuciones de sus órganos, organización de sus servicios (art. 22 y 23), las formas de colaboración con otros entes locales, la participación popular (art. 6) la descentralización (art. 13), el acceso de los ciudadanos a la información (4) (art. 7), la creación de la figura del Defensor municipal de los ciudadanos (art. 8). El estatuto ha de señalar, por ejemplo, el número de consejeros que tendrá la Junta Municipal, órgano similar a nuestra Comisión de Gobierno, entre un número máximo fijado según estratos de población (art. 33).

5) En cuanto al control sobre los órganos se mantienen las técnicas tradicionales de disolución y suspensión de los Consejos municipales y provinciales (art. 39) y de destitución y suspensión de las autoridades locales (art. 40) si bien se advierte el esfuerzo del legislador para perfeccionar los supuestos en los que se actúan estos poderes administrativos que corresponden a los órganos de la Administración del Estado. Por ejemplo, se mantiene la posibilidad de disolver un Ayuntamiento por falta de aprobación de su presupuesto en los plazos legales (art. 39, $1 \mathrm{c}$ ). Quiero recordar, frente a la ingenuidad $y$ al complejo que ha demostrado el legislador español, que en Italia es frecuente el uso de estos poderes para poner término a situaciones de funcionamiento anormal de los entes locales. Según los datos facilitados

(3) Véase entre otros, F. STADERINI, Diritto degli enti locali, 2s Ed. Padova, 1989, pp. 49-74.

(4) Téngase en cuenta que con posterioridad se ha aprobado la ley 241 , de 7 de agosto de 1990, que regula nuevas normas en materia de procedimiento administrativo $y$ el derecho de acceso a los documentos administrativos, texto que yo mismo he traducido y que ha de publicar próximamente la Revista Administración Pública. 
por L. LOLLI (5) en un trabajo reciente, durante el período 1980-1988 han sido disueltas 25 Unidades Sanitarias Locales y 220 Ayuntamientos, de ellos 144 por falta de aprobación del Presupuesto (6).

6) En cuanto al control de los actos, condicionado en parte por las previsiones del art. 130 de la Constitución italiana que atribuye a un órgano de la región el control de legalidad de los actos locales, respetando dicha previsión se ha perfeccionado el mecanismo, limitando las categorías de actos (los acuerdos competencia de los Consejos municipales y Provinciales, esto es de los Plenos) que necesariamente deben pasar el control preventivo de legalidad encomendado al Comité Regional de Control (art. 45), así como aquellos otros que por propia iniciativa decidan someter el Consejo o un número determinado de consejeros (un tercio o un quinto según la cifra de población). Adviértase que el Comité Regional de Control es un órgano administrativo de la Región (si bien sus aspectos básicos están regulados por ley del Estado, arts. 41, 42, 43) y que sus acuerdos son susceptibles de recurso ante los Tribunales Administrativos. Adviértase, además, que los acuerdos locales sujetos al control preventivo de legalidad no son ejecutivo hasta veinte días después de su recepción por el Comité (art. 46,1), salvo que el Comité expresamente comunique antes de ese plazo la ausencia de vicios de legalidad (art. 46,5) o sean declarados urgentes mediante el voto de la mayoría de los miembros del Consejo (art. 47,2). Ninguna previsión de este tenor existe en nuestro país. Por ello los actos locales son inmediatamente ejecutivos, aunque sean ilegales.

7) $\mathrm{Ha}$ de tenerse en cuenta que la ley no se aplica a las Regiones de Estatuto especial ni a las provincias de Trento y Bolzano en cuanto se oponga a lo previsto en los respectivos Estatutos o en las leyes que los hayan desarrollado (art. 1,2). El resto de las Regiones tiene importantes funciones en aspectos organizativos y competenciales derivados de las previsiones de la legislación estatal. Por lo demás, el legislador estatal se ha impuesto como regla de conducta el respeto de los principios recogidos en la ley que no podrá derogar salvo expresa modificación de sus preceptos (art. 1,3).

(5) L. LOLLI, "I controlli sugli organi degli enti locali 1980-1988", Regione e Governo locale, 4(1989), pp. 67-94.

(6) Como dato revelador téngase en cuenta que el Ayuntamiento de Nápoles (1.206.010 habitantes) ha sido disuelto por falta de aprobación del presupuesto en dos ocasiones (los años 1982 y 1986. ¡Sin duda un hecho inimaginable en nuestro país dado el actual sistema legal! 
8) Del apartado de Hacienda y presupuesto destacaria el sistema de revisión económico-financiera interna (previa, por tanto, a la intervención del Tribunal de Cuentas) encomendada a un Colegio de Censores integrado por profesionales ajenos a la propia Corporación (art. 57).

Por todo ello, considero del máximo interés dar a conocer el contenido de esta ley, por varias razones. En primer lugar, para que el legislador estatal tome buena nota de las experiencias extranjeras y verifique la funcionalidad de nuestro sistema normativo local (particularmente deficiente en materia de controles). En segundo lugar, por que en este momento distintas Comunidades Autónomas anuncian su propósito de aprobar leyes sobre régimen municipal en sus diferentes aspectos, $y$ bueno será que tengan en consideración las respuestas dadas por el legislador italiano.

Acaba de salir, por cierto un temprano comentario a la ley debido a la firma del cualificado especialista en la materia, prof. L. VANDELLI, un libro de 448 páginas titulado Ordinamento delle autonomie locali, Commento alla legge 8 giugno 1990, n 142. Norme complementari. Documenti. Schemi, Maggioli Editore, Rimini, 1990. Se trata de un comentario, artículo por artículo, que se abre con las referencias constitucionales así como con los antecedentes y que expone las líneas claves de la reforma. Se completa con importantes apéndices normativos -la normativa anterior mantenida en vigor, la ley italiana de ratificación de la Carta Europea de las Autonomía locales, y una Circular del Ministerio del Interior sobre la propia Ley comentada- así como una serie de cuadros y esquemas comparando sobre diversos puntos (Alcalde, la Junta, consorcios, áreas metropolitanas, funciones de las regiones, funciones de la Administración del Estado, etc.) la situación anterior con la nueva.

Quiero advertir, en fin, en cuanto a la traducción que, al margen de las precisiones concretas que hago a lo largo de la misma, he procurado, utilizar la terminología jurídico-administrativa propia de nuestros textos legales de régimen local para facilitar la comprensión de su significado, si bien manteniendo el máximo respeto al espíritu del texto italiano. 


\title{
LEY DE 8 DE JUNIO DE 1990, № 142, ORDENAMIENTO DE LA AUTONOMIAS LOCALES,
}

\author{
LA CAMARA DE LOS DIPUTADOS Y EL \\ SENADO DE LA REPUBLICA HAN APROBADO;
}

\author{
EL PRESIDENTE DE LA REPUBLICA \\ promulga la siguiente ley: \\ CAPITULO I \\ PRINCIPIOS GENERALES
}

\section{Art. 1 (Objeto de la Ley)}

1. La presente ley regula los principios del ordenamiento de los municipios y de las provincias y determina sus funciones.

2. Las disposiciones de la presente ley no se aplicarán a las regiones de Estatuto especial ni a las provincias autónomas de Trento y de Bolzano en cuanto sean incompatibles con las atribuciones previstas por los Estatutos y por las correspondientes normas de desarrollo.

3. De acuerdo con el art. 128 de la Constitución, las leyes de la República no podrán derogar los principios de la presente ley sino mediante expresa modificación de sus preceptos.

\section{Art. 2 (Autonomía de los municipios y de las provincias)}

1. Las comunidades locales, ordenadas en municipios y provincias, son autónomas.

2. El municipio es un ente local que representa la propia comunidad, gestiona sus intereses y promueve su desarrollo.

3. La provincia, ente local intermedio entre municipio y región, gestiona sus intereses y promueve el desarrollo de la comunidad provincial.

4. Los municipios y las provincias tienen autonomía estatutaria y autonomía financiera en el ámbito de las leyes y de la coordinación de las haciendas públicas.

5. Los municipios y las provincias son titulares de funciones propias. Ejercitan además, según las leyes estatales y regionales, las funciones atribuidas o delegadas por el Estado y por la región. 


\section{Art. 3 (Relaciones entre Regiones y Entes Locales)}

1. De acuerdo con el art. 117, párrafos primero y segundo, y con el art. 118, párrafo primero de la Constitución, sin perjuicio de las funciones que tengan en cuenta necesidades de carácter unitario de los respectivos territorios, las regiones organizarán el ejercicio de las funciones administrativas a nivel local a través de los municipios y las provincias.

2. Al objeto de lo previsto en el párrafo primero, las leyes regionales se adecuarán a los principios establecidos en la presente ley en relación a las funciones del municipio y de la provincia, identificando en la materias y en los casos previstos en el art. 117 de la Constitución los intereses municipales y provinciales en atención a las características de la población y del territorio.

3. Las leyes regionales regularán la cooperación de los municipios y de las provincias entre sí y con la región, con el objeto de lograr un sistema eficaz de la autonomías locales al servicio del desarrollo económico, social y civil.

4. Las regiones determinarán los objetivos generales de la programación económico-social y territorial y sobre esta base distribuirán los recursos destinados a la financiación del programa de inversiones de los entes locales.

5. Los municipios y las provincias concurrirán a la determinación de los objetivos recogidos en los planes y programas del Estado y de las regiones y procederán, en lo que sean competentes, a su concreción y aplicación.

6. Las Leyes regionales establecerán las reformas y modalidades de la participación de los entes locales en la elaboración de planes y programas regionales y de los otros instrumentos de la región.

7. Las leyes regionales fijarán los criterios y el procedimiento para la elaboración y ejecución de los actos y de los instrumentos de la programación socio-económica y de la planificación territorial de los municipios y de las provincias relevantes para la ejecución de los programas regionales.

8. Las leyes regionales regularán, asimismo, mediante normas de carácter general, los modos y procedimientos para la comprobación de la compatibilidad entre los instrumentos previstos en el párrafo 7 y los programas regionales, caso de que existan. 
CAPITULO $\|$

\section{AUTONOMIA ESTATUTARIA Y POTESTAD REGLAMENTARIA}

\section{Art. 4 (Estatutos municipales y provinciales)}

1. Los municipios y las provincias aprobarán su estatuto.

2. El estatuto, en el ámbito de los principios fijados por la lay, establecerá las normas fundamentales de la organización del ente y, en particular, determinarán las atribuciones de los órganos, la ordenación de las dependencias y de los servicios públicos, las formas de colaboración entre municipios y provincias, la participación popular, la descentralización, el acceso de los ciudadanos a la información y a los procedimientos administrativos.

3. Los estatutos serán aprobados por los respectivos Consejos con el voto favorable de dos tercios del número legal de consejeros. Cuando no se alcance dicha mayoría, se repetirá la votación en sucesivas sesiones que se celebrarán en el plazo de treinta días y el estatuto quedarán aprobado si obtiene, por dos veces, el voto favorable de la mayoría absoluta del número legal de consejeros. Las disposiciones del presente párrafo se aplicarán, también, a las modificaciones estatutarias.

4. Tras pasar el control del órgano regional competente, el estatuto se publicará en el boletín oficial de la Región, se expondrá en el tablón de edictos del ente durante treinta días consecutivos y se enviarán al Ministerio del Interior para ser inscrito en la recopilación oficial de estatutos en el boletín oficial de las Región.

\section{Art. 5 (Reglamentos)}

1. Con respecto a la ley y al estatuto, el municipio y la provincia aprobarán reglamentos para la organización y el funcionamiento de las instituciones y de los organismos de participación, para el funcionamiento de los órganos y de los servicios y para el ejercicio de las funciones.

CAPITULO III

INSTITUTOS DE PARTICIPACION

\section{Art. 6 (Participación popular)}

1. Los municipios favorecerán (1) las formas asociativas libre y promoverán órganos (2) de participación de los ciudadanos en la Ad-

(1) Traduzco "valorizzano" en el contexto de la frase por "favorecerán".

(2) Traduzco "organismi" en el contexto de la frase por "órganos". 
ministración local, tomando como base los barrios o los distritos (3). El estatuto regulará las relaciones de esas formas asociativas con el municipio.

2. En el procedimiento relativo a la adopción de los acuerdos que incidan en situaciones jurídicas subjetivas se establecerán formas de participación de los interesados según las modalidades previstas en el estatuto.

3. En el estatuto se establecerán formas de consulta de la población así como procedimientos para la admisión de solicitudes, peticiones y propuestas de los ciudadanos individuales o asociados dirigidas a promover actuaciones para la mejor tutela de los intereses colectivos y deberán, además, determinarse las garantías para su oportuna consideración. Podrán establecerse, también referéndumes consultivos a petición de un adecuado número de ciudadanos.

4. Las consultas y los referéndumes consultivos previstos en el presente artículo deberán referirse a materias de exclusivo competencia local y no podrán coincidir con otros procesos electorales.

\section{Art. 7 (Acción popular, derechos de acceso y de información de los ciudadanos)}

1. Cualquier elector podrán hacer valer, ante la jurisdicción administrativa, las acciones y recursos que correspondan al municipio.

2. El juez ordenará la instrucción del proceso contra el municipio. En caso de desestimación, los gasto correrán a cargo de quien haya promovido la acción o del recurso.

3. Todos los actos de la Administración municipal y provincial serán públicos, a excepción de aquellos reservados por indicación expresa de la ley o por efecto de una oportuna y motivada resolución del Alcalde o del Presidente de la provincia, que prohiba su exhibición, conforme a lo previsto en el reglamento, en cuanto su difusión pueda prejuzgar el derecho a la intimidad de las personas, de los grupos o de las empresas.

4. El reglamento asegurará a los ciudadanos individuales y asociados el derecho de acceso a los documentos (4) administrativos y regulará la expedición de copias de actos, previo pago exclusivamente de su coste; determinará, mediante las normas de organización de las dependencias y de los servicios, el responsable de los procedimientos; dictará las normas necesa-

(3) Traduzco "frazioni" por "distritos".

(4) Traduzco "atti" en el contexto de la frase por "documentos" 
rias para asegurar a los ciudadanos la información sobre el estado de los actos y de los procedimientos y sobre el orden de examen de las peticiones, proyectos y resoluciones que le afecten de cualquier modo; asegurará el derecho de los ciudadanos en general, a la información que posea la Administración.

5. Con el objeto de hacer efectiva la participación de los ciudadanos en la actividad de la Administración, los entes locales garantizarán el acceso a las estructuras y a los servicios de los entes, a las organizaciones voluntarias y a las asociaciones.

\section{Art. 8 (Defensor ciudadano)}

1. El estatuto provincial y el municipal podrán establecer la creación del Defensor ciudadano, que desarrollará la función de garante de la imparcialidad y de la buena marcha de la Administración pública municipal o provincial, señalando, incluso a iniciativa propia, los abusos, las disfunciones, las carencias y los retrasos de la Administración sus relaciones con los ciudadanos.

2. El estatuto regulará la elección, las prerrogativas y los medios del Defensor ciudadano así como sus relaciones con el Consejo municipal y provincial.

\section{CAPITULO IV \\ EL MUNICIPIO}

\section{Art. 9 (Funciones)}

1. Corresponde al municipio todas las funciones administrativas que afecten a la población y al territorio municipal principalmente en los sectores orgánicos de los servicios sociales, de la ordenación y utilización del territorio y del desarrollo económico, salvo cuando esté expresamente atribuido a otros sujetos por la ley estatal o regional, según las respectiva competencias.

2. El municipio, para el ejercicio de las funciones en ámbitos territoriales adecuados, establecerá formas de descentralización o de cooperación con otros municipios y con la provincia. 


\section{Art. 10 (Obligaciones del municipio en relación a servicios de competencia estatal)}

1. El municipio gestionará los servicios electorales, el Censo de Población, el Registro Civil (5), la estadística y el reclutamiento militar.

2. Las correspondientes funciones serán ejercidas por el Alcalde como delegado del Gobierno.

3. Podrán atribuirse a los municipios mediante ley, que regulará las correspondientes relaciones financieras que aseguren los recursos necesarios, otras funciones administrativas relativas a servicios de competencias estatal.

\section{Art. 11 (Modificaciones territoriales, fusiones e instituciones comunes)}

1. De acuerdo con los arts. 117 y 133 de la Constitución, las regiones podrán modificar las circunscripciones territoriales de los municipios, oída la población interesada, según las formas previstas por la ley regional. Salvo los casos de fusiones entre varios municipios, no podrán crearse nuevos municipios con población inferior a los 10.000 habitantes o cuya creación suponga, como consecuencia, que otros municipios desciendan bajo tal límite.

2. Las regiones elaborarán un programa de modificación de las circunscripciones municipales y lo actualizarán cada cinco años, teniendo en cuenta las uniones continuidad de acuerdo con el art. 26.

3. Las leyes regionales que creen nuevos municipios, mediante fusión de dos o más municipios contiguos, cuidarán que en las comunidades de origen o en algunas de ellas queden garantizadas formas adecuadas de participación y de descentralización de los servicios.

4. Con el objeto de favorecer la fusión de municipios con población inferior a 5.000 habitantes incluso con municipios de población superior, junto a las eventuales ayudas de las Regiones, el Estado concederá, durante los diez años siguientes a la fusión, ayudas propias extraordinarias determinadas en función de una cuota de las transferencias correspondientes a los municipios individuales que se fusionen.

5. En caso de fusión de dos o más municipios con población inferior a 5.000 habitante o uno o más municipios con población superior, las ayudas extraordinarias se calcularán solamente para los municipios con población superior, las ayudas extraordinarias se calcula-

(5) Traduzco "stato civile" por "Registro Civil". 
rán solamente para los municipios con población inferior a 5.000 habitantes y se consignarán en el presupuesto del municipio resultante de la fusión, con obligación de destinar no menos del 70 por ciento a gastos exclusivamente al territorio y a servicios prestados en el ámbito territorial de los municipios suprimidos, que tengan una población inferior a 5.000 habitantes.

\section{Art. 12 (Entidades Locales Menores (6))}

1. Las leyes regionales previstas en el párrafo 3 del art. 11, podrá establecer la creación de entidades locales menores en el territorio de las comunidades previstas en el párrafo 4 del mismo artículo, con la función de gestionar los servicios de base así como otras funciones delegadas por el municipio.

2. El estatuto del municipio regulará la elección, simultáneamente al Consejo municipal, de un Alcalde (7) y de dos vocales (8) por los ciudadanos residentes en la entidad local menor, con arreglo a listas concurrentes y entre candidatos alli residentes y elegibles a consejeros municipales.

3. Serán proclamados electos los candidatos de la lista que obtenga mayor número de votos. El cargo de Alcalde pedáneo y de vocales será incompatible con el de consejero municipal.

4. En lo no previsto por el presente artículo se estará a lo dispuesto en el estatuto o reglamento municipal.

5. Se aplicarán a las autoridades de las entidades locales menores, las normas previstas para las autoridades de los municipios de igual población.

\section{Art. 13 (Circunscripciones de descentralización municipal)}

1. Los municipios capital de provincia y los municipios de población superior a 100.000 habitantes articularán su territorio creando circunscripciones de descentralización, como órganos de participa-

(6) He traducido "municipi" por "entidades locales menores", por cuanto que en la terminología legal italiana la voz "comune" corresponde con la española "municipio", correspondiendo el contenido de la voz "municipi" a nuestras "entidades locales menores", ahora, según la terminologia de la Ley Reguladora de la Base de Régimen Local, "entidades de ámbito territorial inferior al municipal".

(7) Traduzco "pro-sindaco", por la correspondiente figura en las Entidades locales menores, Alcalde Pedáneo.

(8) Traduzco "consultori" por vocales. 
ción, de consulta y de gestión de servicios de base, así como de ejercicio de funciones delegadas por el municipio.

2. La organización y las funciones de las circunscripciones serán reguladas por el estatuto municipal y por el reglamento que lo desarrolle.

3. Los municipios con población entre 30.000 y 100.000 habitantes podrán articular el territorio municipal creando circunscripciones de descentralización según lo previsto en el párrafo 2.

4. El Consejo circunscripcional gestiona las necesidades de la población de la circunscripción en el ámbito de la unidad del municipio y será elegido por sufragio directo según las normas establecidas para la elección de los Consejos municipales con la población superior a 5.000 habitantes.

5. El Consejo circunscripcional elegirá de entre sus miembros un presidente.

6. Queda derogada la ley de 8 de abril de 1976 , no 278 , y posteriores modificaciones $y$ desarrollos.

\section{CAPITULO V}

\section{LA PROVINCIA}

\section{Art. 14 (Funciones)}

1. Corresponden a la provincia las funciones administrativas de interés provincial que afecten a amplias zonas supramunicipales o a la totalidad del territorio provincial en los siguientes sectores.

a) defensa del suelo, tutela y protección del ambiente y prevención de las calamidades.

b) tutela y protección de los recursos hídricos y energéticos.

c) protección de los bienes culturales.

d) vialidad y transportes.

e) protección de la flora y de la fauna, parques y reservas naturales.

f) caza y pesca en las aguas interiores.

g) organización de la recogida de basuras en el ámbito provincial, trazado, regulación y control de los vertidos de aguas y de las emisiones atmosféricas y sonoras.

h) servicios sanitarios, de higiene y profilaxis pública, atribuidas por la legislación estatal o regional.

i) funciones relacionadas con la enseñanza secundaria de segundo grado y artística y con la formación profesional, comprendidas las construcciones escolares, atribuidas por la legislación estatal o regional. 
j) recogida y elaboración de datos, asistencia técnico-administrativa a los entes locales.

2. La provincia, en colaboración con los municipios y mediante programas, promoverá y coordinará actividades así como realizará obras de relevante interés provincial sea en el sector económico, productivo, comercial y turístico, sea en el social, cultural y deportivo.

3. La gestión de tales actividades y obras se realizará a través de las formas previstas en la presente ley para gestión de los servicios públicos.

\section{Art. 15 (Funciones de programación)}

1. La provincia

a) reunirá y coordinará las propuestas presentadas por los municipios, relativas a la programación económica, territorial y ambiental de la región.

b) concurrirá a al determinación del programa regional de desarrollo y de los otros programas y planes regionales según las normas dictadas por las leyes regionales.

c) formulará y aprobará, en relación a las previsiones y a los objetivos del programa regional de desarrollo, programas propios plurianuales tanto de carácter general como sectorial y promoverá la coordinación de la actividad programadora de los municipios.

2. La provincia, además, elaborará y aprobará el plan territorial de coordinación que, sin perjuicio de las competencias de los municipios y en ejecución de la legislación regional, determinará las directrices generales de la ordenación del territorio y, en particular, indicará.

a) los diversos usos del territorio en atención al destino prevalente de sus partes.

b) la localización en sus aspectos generales de las grandes infraestructuras y de las principales lineas de comunicación.

c) las líneas de intervención para la ordenación hídrica, hidrogeológica e hidráulico-forestal y en general para la consolidación del suelo y del régimen del agua.

d) las áreas en las que sea oportuno crear parques o reservas naturales.

3. Los programas plurianuales y el plan territorial de coordinación se enviarán a la región con el objeto de comprobar su adecuación a las directivas regionales de la programación socio-económica y territorial. 
4. Las leyes regionales regularán el procedimiento de aprobación así como normas que aseguren la participación de los municipios en la elaboración de los programas plurianuales y de los planes territoriales de coordinación.

5. Con el objeto de coordinar y aprobar los instrumentos de planificación territorial elaborados por los municipios, la provincia ejercerá las funciones que le atribuya la región y tendrá, en todo caso, la función de comprobar la adecuación de dichos instrumentos con las previsiones del plan territorial de coordinación.

6. Los entes y las Administraciones Públicas, en el ejercicio de las respectivas competencias, se ajustarán a los planes territoriales de coordinación de la provincia y tendrán en cuenta su programación plurianual.

\section{Art. 16 (Circondarios (9) y revisión de las circunscripciones provinciales)}

1. La provincia, en relación a la extensión y peculiaridad del territorio, a las necesidades de la población y a la funcionalidad de los servicios, podrá regular en el estatuto la subdivisión del propio territorio en circondarios y organizar sobre su base, las dependencias y los servicios y la participación de los ciudadanos.

2. Para la revisión de los circunscriptores provinciales y la creación de nuevas provincias los municipios ejercerán la iniciativa prevista en el art. 133 de la Constitución, teniendo en cuenta los siguientes criterios y directivas:

a) Todo territorio provincial debe pertenecer a la zona dentro de la que se desarrolla la mayor parte de las relaciones sociales, económicas y culturales de la población residente.

b) todo territorio provincial debe tener una dimensión tal, por extensión, entidad demográfica, así como por las actividades productivas existentes o posibles, que permita una programación del desarrollo que favorezca el equilibrio económico, social y cultural del territorio provincial y regional.

c) la totalidad del territorio de cada municipio debe pertenecer a una sola provincia.

d) la iniciativa de los municipios, prevista en el art. 133 de la Constitución, deberá lograr la adhesión de la mayoría de los municipios del área interesada, que representen, en todo caso, la mayoria de la población total de dicha área, mediante acuerdo adoptado por mayoría absoluta del número legal de los consejeros.

(9) He preferido mantener la expresión "circondarios" ("circondari") que viene a ser nuestra "comarca", en cuanto espacios supramunicipales. 
e) por lo general, la población de las provincias resultantes de la modificación territorial no deberá ser inferior a 200.000 habitantes.

f) la creación de nuevas provincias no conllevará necesariamente la creación de dependencias provinciales de la Administración del Estado y de los otros entes públicos.

g) las provincias preexistentes deberán garantizar a las nuevas, en proporción al territorio y a la población transferida, personal, bienes, medios operativos y recursos financieros adecuados.

3. De acuerdo con el párrafo segundo del art. 117 de la Constitución las regiones aprobarán normas dirigidas a promover y a coordinar la iniciativa de los municipios prevista en la letra d) del apartado 2.

\section{CAPITULO VI}

\section{AREAS METROPOLITANAS}

\section{Art 17 (Areas metropolitanas)}

1. Se consideran áreas metropolitanas las zonas que comprenden los municipios de Turín, Milán, Venecia, Génova, Bolonia, Florencia, Roma, Bari, Nápoles y los otros municipios cuyo territorio tenga con ellos relaciones de estrecha integración en orden a las actividades económicas, a los servicios esenciales para la vida social, así como a las relaciones culturales y a las características territoriales.

2. En el plazo de un año desde la fecha de entrada en vigor de la presente ley, las regiones procederán a la delimitación territorial de cada área metropolitana, oídos los municipios y provincias afectados.

3. Cuando el área metropolitana no coincida con el territorio de una provincia se procederá a la nueva delimitación de la circunscripción provincial o a la creación de nuevas provincias, de acuerdo con el art. 16, considerando el área metropolitana como territorio de una nueva provincia.

4. En el área, la provincia se configurará como autoridad metropolitana con potestad propia y asumirá la denominación de "ciudad metropolitana".

5. En la aplicación del art. 43 de la ley constitucional de 26 de febrero de 1948, no 3, (Estatuto especial para Cerdeña), la Región de Cerdeña podrá mediante ley, desarrollar los previsto en el presente artículo, delimitando el área metropolitana de Cagliari. 


\section{Art. 18 (Ciudad metropolitana)}

1. En el área metropolitana, la Administración local se articulará en dos niveles:

a) ciudad metropolitana

b) municipios

2. Hasta la aprobación de una normativa, se aplicarán a la ciudad metropolitana las normas relativas a la provincia, en cuanto sean compatibles, incluidas las electorales.

3. Son órganos de la ciudad metropolitana: el Consejo metropolitano, la Junta metropolitana y el Alcalde metropolitano.

4. El Alcalde preside el Consejo y la Junta.

\section{Art. 19 (Funciones de la ciudad metropolitana y de los municipios)}

1. Las leyes regionales, al distribuir las funciones administrativas entre los municipios y la ciudad metropolitana, atribuirán a la ciudad metropolitana, además de las funciones de competencia provincial, las funciones normalmente atribuidas a los municipios cuando tengan carácter principalmente supramunicipal o deban, por razones de economía y de eficiencia, ser desarrolladas de forma coordinada en el área metropolitana, en el ámbito de las siguientes materias:

a) planificación territorial del área metropolitana;

b) vialidad, tráfico y transportes;

c) tutela y protección de los bienes culturales y del ambiente;

d) defensa del suelo, tutela hidrogeológicas, tutela y protección de los recursos hídricos, recogida de basuras;

e) captación y distribución del agua y de las fuentes energéticas;

f) servicios para el desarrollo económico y gran distribución comercial;

g) servicios de áreas extensas en los sectores de la sanidad, de la escuela y de la formación profesional y de los otros servicios urbanos de ámbito metropolitano.

2. Corresponden a la ciudad metropolitana las tasa, las tarifas y las contribuciones de los servicios a ella atribuidos.

3. Corresponden a los municipios del área metropolitana las funciones no atribuidas expresamente a la ciudad metropolitana.

\section{Art. 20 (Reordenación de las circunscripciones territoriales de los municipios del área metropolitana)}

1. En el plazo de dieciocho meses desde la delimitación del área metropolitana, la región, oídos los municipios afectados, procederá a 
reordenar las circunscripciones territoriales de los municipios del área metropolitana.

2. Con tal objeto, las Regiones procederán a la creación de nuevos municipios por segregación de áreas de intensa urbanización o por fusión de municipios limitrofes, en atención a su grado de autonomía, de organización y de funcionalidad, de modo que asegure el pleno ejercicio de las funciones municipales, la racional utilización de los servicios, la responsable participación de los ciudadanos así como una equilibrada relación entre dimensión territorial y demográfica.

3. Los nuevos municipios, segregados del municipio que comprenda el centro histórico, conservarán la denominación originaria a la que se le añadirá aquélla más característica de los barrios o de las circunscripciones que los compongan.

4. El municipio preexistente transferirá a los nuevos municipios, en proporción los habitantes y al territorio, recursos y personal así como adecuados bienes instrumentales muebles $\mathrm{e}$ inmuebles.

\section{Art. 21 (Delegación al Gobierno)}

1. Se delega al Gobierno la potestad de dictar, en el plazo de veinticua tro meses desde la fecha de entrada en vigor de la presente ley, previo informe de la Comisión parlamentaria correspondiente, los adecuados decretos legislativos para la constitución, a propuesta de las respectivas regiones de las autoridades metropolitanas en las áreas a que se refiere el art. 17.

2. Los decretos, que habrán de tener en cuenta la especificidad de cada una de las áreas, se adecuarán a los criterios previstos en los artículos precedentes.

3. Ante la falta o retraso de la propuesta regional, el Gobierno resolverá directamente.

4. Cuando la Región no proceda al cumplimiento previsto en al art. 20, el Gobierno, por acuerdo del Consejo de Ministros, requerirá a la Región a cumplirlo. Transcurridos infructuosamente seis meses, se delega en el Gobierno la potestad de dictar decretos legislativos, respetando los criterios previstos en el art. 20, oídos los municipios afectados y previo informe de la Comisión parlamentaria correspondiente.

\section{CAPITULO VII}

\section{SERVICIOS}

\section{Art. 22 (Servicios públicos locales)}

1. Los municipios y las provincias, en el ámbito de las respectivas competencias, gestionarán los servicios públicos que tengan por 
objeto la producción de bienes y actividades dirigidas a la consecución de fines sociales y a promover el desarrollo económico y civil de las comunidades locales.

2. La ley establecerá los servicios reservados con carácter exclusivo a los municipios y a las provincias.

3. Los municipios y las provincias pueden gestionar los servicios públicos en las formas siguientes:

a) por administración (10), cuando por las modestas dimensiones o por las características del servicio no sea oportuno crear un establecimiento (11) o un organismo autónomo (12).

b) mediante concesión a terceros, cuando concurran razones técnicas, económicas y de oportunidad social.

c) por medio de organismo autónomo, incluso para la gestión de más servicios de carácter económico y empresarial.

d) por medio de establecimiento, para el ejercicio de servicios sociales que no tengan carácter empresarial;

e) por medio de sociedad por acciones con mayoría de capital público local, cuando se considere oportuna, en relación a la naturaleza del servicio a establecer, la participación de otros sujetos públicos o privados.

\section{Art. 23 (Organismos autónomos y establecimientos)}

1. El organismo autónomo es un ente instrumental del ente local dotado de personalidad jurídica, de autonomía empresarial y de estatuto propio, aprobado por el Consejo municipal o provincial.

2. El establecimiento es un organismos instrumental del ente local para el ejercicio de servicios sociales, dotado de autonomía de gestión.

3. Son órganos del organismo autónomo y del establecimiento el Consejo de Administración, el Presidente y el Director, al que corresponde la responsabilidad de la gestión. El estatuto del ente local establecerá las modalidades de nombramiento y cese de los administradores.

4. Los organismos y los establecimientos realizarán su actividad con criterios de eficacia, eficiencia y economicidad y respeta-

(10) Traduzco "in economía" por "administración", una de las formas de ejecución de los contratos públicos: el de obras (art. 187 Reglamento Contratados del Estado) y el de servicios públicos (art. 236 del mismo Reglamento) en nuestro Derecho.

(11) Traduzco en el contexto de este articulo "istituziones" por "establecimiento".

(12) Traduzco "azienda" $y$ "azienda speciale" por "organismo autónomo". 
rán el equilibrio presupuestario mediante de igualdad de costes y beneficios, incluidas las transferencias.

5. En el ámbito de la ley, el ordenamiento y el funcionamiento de los organismos autónomos será regulado por el estatuto y por los reglamentos del ente local del que dependan.

6. El ente local otorgará el capital de dotación; determinará la finalidad y la dirección; aprobará los acuerdos fundamentales; ejercitará la vigilancia; verificará los resultados de la gestión; cubrirá los eventuales costes sociales.

7. La Comisión de censores de cuentas del ente local ejercerá sus funciones también respecto de los establecimientos. EI estatuto del organismo autónomo creará un órgano específico de revisión, así como formas autónomas de fiscalización de la gestión.

\section{CAPITULO VIII \\ FORMAS ASOCIATIVAS Y DE COOPERACION. ACUERDOS DE PROGRAMA}

\section{Art. 24 (Convenios)}

1. Con el objeto de desarrolla de modo coordinado funciones y servicios determinados, los municipios y las provincias podrán estipular entre ellos los oportunos convenios.

2. Los convenios deberán establecer los fines, la duración, las formas de consulta de los entes contratantes, sus relaciones financieras y las obligaciones y garantías recíprocas.

3. Para la gestión por tiempo determinado de un servicio específico o para la realización de una obra, el Estado y la región, en las materias de su competencia, podrán prever formas de convenios obligatorias entre los municipios y las provincias, previo establecimiento de una regulación-tipo.

\section{Art. 25 (Consorcios)}

1. Los municipios y las provincias, para la gestión asociada de uno o más servicios, podrán constituir un consorcio según las normas previstas para los organismos autónomos a que se refiere el art. 23, en cuanto sean compatibles. 
2. Con tal objeto, los respectivos Consejos aprobarán, por mayoría absoluta de los miembros, un convenio de los previstos en el art. 24 junto con el estatuto del consorcio.

3. El convenio deberá prever, en particular, el envío, a los entes adheridos, de los actos fundamentales del consorcio.

4. La asamblea del consorcio estará compuesta por representantes de los entes asociados en la persona del Alcalde, del Presidente o un delegado de ellos, cada uno con responsabilidad igual a la cuota de participación fijada en el convenio y en el estatuto.

5. La asamblea elegirá el Consejo de Administración y aprobará los actos fundamentales previstos en su estatuto.

6. Entre los mismos municipios y provincias no podrá constituirse más de un consorcio.

7. En caso de relevante interés público, la ley del estado podrá prever la constitución de consorcios obligatorios para el ejercicio de determinadas funciones y servicios. Dicha ley encomendará su ejecución a las leyes regionales.

\section{Art. 26 (Uniones de municipios)}

1. En previsión de su fusión, dos o más municipios limítrofes, pertenecientes a la misma provincia, cada uno con población no superior a 5.000 habitantes, podrán constituir una unión para el ejercicio de un pluralidad de funciones o de servicios.

2. No podrá formar parte de la unión más de un municipio con población entre 5.000 y 10.000 habitantes.

3. El acuerdo constitutivo el reglamento de la unión serán aprobados por acuerdo individual de cada uno de los Consejos municipales, por mayoría absoluta del número legal de consejeros.

4. Son órganos de la unión, el Consejo, la Junta y Presidente, que serán elegidos según las normas de ley relativas a los municipios con población igual a la que resulte de la unión. El reglamento podrá prever que el Consejo sea expresión de los municipios participantes en la unión y regulará las formas para ello.

5. El reglamento de la unión contendrá la enumeración de los órganos y de los servicios a unificar, así como las normas relativas a la hacienda de la unión y a las relaciones financiera con los municipios.

6. En el plazo de diez años desde la constitución de la unión deberá procederse a la fusión, según los dispuesto en el art. 11. Cuando no se llegue a la fusión, se disolverá la unión.

7. Corresponderá a la unión de municipios las tasas, tarifas y contribuciones de los servicios gestionados por ella. 
8. Las regiones promoverán la unión de municipios y a tal objeto procederán a la concesión de ayudas complementarias, a los diez años de la constitución de la unión de municipios se constituirá en municipio por ley regional, caso que la fusión no haya sido acordada en dicho plazo, a solicitud de los municipios de la unión.

\section{Art. 27 (Acuerdos de programa)}

1. Para la definición y la ejecución de obras, actuaciones o programas de actuaciones que quieran, para su completa realización, la acción conjunta y coordinada de municipios, provincias y regiones, de administraciones estatales y de otros sujetos públicos 0 , en cualquier caso, de dos o más de entre los sujetos citados, el Presidente de la Región o el Presidente de la provincia o el alcalde, en relación a la competencia principal prevalente sobre la obra o sobre actuaciones o sobre programas de actuación, promoverá la firma de un acuerdo de programa, también a petición de uno o más de los sujetos interesados, para asegurar la coordinación de las acciones y para determinar los plazos, las modalidades, la financiación y cualquier otro cumplimiento conexo.

2. El acuerdo podrá prever, además, procedimientos de arbitraje, así como intervenciones subrogatorias ante los eventuales incumplimientos de los sujetos participantes.

3. Para verificar la posibilidad de concertar el acuerdo de programa, el Presidente de la región o el Presidente de la provincia o el Alcalde convocará una conferencia entre los representantes de todas las Administraciones interesadas.

4. El acuerdo, logrado por consenso unánime de las Administraciones interesadas, será aprobado por acto formal del Presidente de la región o del Presidente de la provincia o del Alcalde y será publicado en el Boletín Oficial de la región. El acuerdo, caso que sea adoptado por Decreto del Presidente de la región, producirá los efectos de los pactos previstos en el art. 81 del Decreto del Presidente de la República, de 24 de julio de 1977, no 616, determinando las eventuales y sucesivas variaciones de los instrumentos urbanísticos y sustituyendo las licencias de obras, siempre que haya existido asentimiento del municipio interesado.

5. Cuando el acuerdo suponga modificación de los instrumentos urbanísticos, la adhesión del Alcalde al mismo deberá ratificarse por el Consejo municipal en el plazo de treinta días bajo sanción de nulidad (13).

(13) Traduzco "decadenza" en este contexto por "nulidad". 
6. La vigilancia de la ejecución del acuerdo de programa y de las eventuales intervenciones sustitutivas será ejercida por un Colegio presidido por el Presidente de la Región, o el Presidente de la provincia o el Alcalde y compuesto por representantes de los entes locales interesados, así como por el Comisario del Gobierno en la Región o por el Prefecto de la provincia interesada, si en el acuerdo participan Administraciones estatales o entes públicos nacionales.

7. Cuando la actuación o el programa de actuación conlleve la participación de dos o más Regiones limítrofes, la conclusión del acuerdo de programa será promovida por el Presidente del Consejo de Ministro, al que corresponderá convocar la conferencia prevista en el párrafo 3. El colegio de vigilancia previsto en el párrafo 6 será, en tal caso, presidido por un representante de la Presidencia del Consejo de Ministros y estará compuesto por los representantes de todas las regiones que hayan participado en el acuerdo. La Presidencia del Consejo de Ministros ejercerá las funciones atribuidas en el párrafo 6 al Comisario del Gobierno y al Prefecto.

8. La regulación prevista en el presente artículo se aplicará a todos los acuerdos de programa previstos en las leyes vigentes relativos a obras, actuaciones o programas de actuación de competencia de las Regiones, de las provincias o de los municipios, salvo los casos en los que el correspondiente procedimiento esté ya formalmente iniciado en la fecha de entrada en vigor en el vigor de la presente ley. Quedan a salvo las competencias previstas en art. 7 de la ley de 1 de marzo de 1986, $n^{\circ} 64$.

\section{CAPITULO IX}

\section{COMUNIDADES DE MONTAÑA}

\section{Art. 28 (Naturaleza y fin)}

1. Las comunidades de montaña son entidades locales constituidas por leyes regionales entre municipios de montaña y parcialmente de montaña de la misma provincia, con la finalidad de promover la protección de las zonas de montaña, el ejercicio asociado de las funciones municipales, asi como la fusión de todos o parte de los municipios asociados.

2. Las comunidades de montaña tienen autonomía estatutaria en el ámbito de las leyes estatales y regionales y no pondrán, en general, tener una población inferior a 5.000 habitantes. Se excluirá, en todo caso, de las comunidades de montaña los municipios con pobla- 
ción total superior a $\mathbf{4 0 . 0 0 0 ~ h a b i t a n t e s ~ y ~ l o s ~ m u n i c i p i o s ~ p a r c i a l m e n t e ~}$ de montaña en los que la población residente en el territorio de montaña sea inferior al 15 por ciento de la población total. Dicha exclusión no privará a los respectivos territorios de montaña de los beneficios y de las actuaciones especiales para la montaña de los beneficios y de las actuaciones especiales para la montaña establecidas por la Comunidad Europea o por las leyes estatales y regionales.

3. Las leyes regionales podrán establecer la exclusión de la comunidad de montaña de aquellos municipios parcialmente de montaña que puedan prejuzgar la homogeneidad geográfica o socio-económica; podrán establecer, además, la inclusión de aquellos municipios colindantes, de población no superior a $\mathbf{2 0 . 0 0 0}$ habitantes que formen parte integrante del sistema geográfico y socio-económico de la comunidad.

4. Con el objeto de graduar y diferenciar las actuaciones de competencia de las regiones y de las comunidad de montaña, las Regiones, por ley propia, podrán proceder a determinar, en el ámbito territorial de cada comunidad de montaña, zonas altimétricas de territorio, teniendo cuenta la configuración orográfica, el clima, la vegetación, la dificultad en la utilización agrícola del suelo, la fragilidad ecológica, los riesgos ambientales y la realidad socio-económica.

\section{Art. 29 (Funciones)}

1. Corresponden a las comunidades de montaña las funciones atribuidas por la ley y las actuaciones especiales para la montaña establecidas por la Comunidad Económica Europea o por las leyes estatales y regionales.

2. El ejercicio asociado de las funciones propias de los municipios o que la región les haya delegado, corresponde a las comunidades de montaña. Corresponde además a las comunidades de montaña el ejercicios de cualquier otra función que les deleguen los municipios, la provincia o la región.

3. Las comunidades de montaña elaborarán planes plurianuales de obras y actuaciones y concretarán los instrumentos idóneos para alcanzar los objetivos del desarrollo socio-económico, incluidos los previstos por la Comunidad Económica Europea, por el Estado y por la Región, que puedan concurrir a la realización de los programas anuales de ejecución del plan.

4. Las comunidades de montaña, mediante las determinaciones urbanísticas del plan de desarrol!o, concurrirán a la elaboración del plan territorial de coordinación. 
5. El plan plurianual de desarrollo socio-económico y sus actualizaciones serán aprobados por las comunidades de montaña y aprobados por la provincia según el procedimiento previsto por las leyes regionales.

6. Las Regiones procederán, mediante las asignaciones previstas en el art. 1 de la ley 23 de marzo de 1981, no 93, a financiar los programas anuales operativos de las comunidades de montaña, sobre la base del reparto a que se refiere el número 3 , del párrafo cuarto del art. 4 de la ley 3 de diciembre 1971, no 1102, del art. 2 de la ciada ley número 93 de 1981.

7. Quedan derogados:

a) el artículo 1 de la ley de 25 de julio de 1952, no 991, que fue sustituido por el artículo único de la ley de 30 de julio de 1957 , no 657, y el párrafo segundo del art. 14 de la citada ley no 991, de 1952.

b) los artículos 3, 5 y 7 de la ley 3 de diciembre de 1971, no 1102 .

8. Las comunidades de montaña podrán transformarse en uniones de municipios, a tenor de lo dispuesto en el art. 26, aunque con derogación de los límites de población.

\section{CAPITULO $X$ \\ ORGANOS DEL MUNICIPIO Y DE LA PROVINCIA}

\section{Art. 30 (Organos)}

1. Son órganos del municipio, el Consejo, la Junta, el Alcalde.

2. Son órganos de la provincia, el Consejo, la Junta, el Presidente.

\section{Art. 31 (Consejo municipal y provincial)}

1. La elección de los consejos municipales y provinciales, la duración de su mandato, el número de consejeros y su estatuto jurídico serán regulados por ley.

2. Los consejeros inician su mandato desde le momento de su proclamación o bien, en caso de subrogación, apenas se haya adoptado por el Consejo el correspondiente acuerdo.

3. El mandato de los Consejos dura hasta la elección de los nuevos, limitándose, tras la publicación del Decreto que fije la fecha de los comicios electorales, a adoptar los acuerdo urgentes e inaplazables. 
4. Cuando el estatuto lo disponga, el Consejo creará Comisiones constituidas de entre sus miembros con criterios de proporcionalidad. El reglamento determinará los poderes de las Comisiones y regulará la organización y las formas de publicidad de los trabajos.

5. Los consejeros municipales y provinciales tienen derecho a obtener de las dependencias del municipio y de la provincia, respectivamente, así como de los organismos y entes dependientes, todos los datos y las informaciones que posean, útiles para el cumplimiento de su mandato. Están obligados al secreto en los caso especificamente determinados por la ley.

6. Los consejeros municipales y provinciales tienen derecho de iniciativa sobre cualquier cuestión sometida a la deliberación del Consejo. Tienen, además, el derecho de presentar preguntas y mociones.

7. El Alcalde o el Presidente de la provincia están obligados a convocar el Consejo, en un plazo no superior a veinte días, cuando lo solicite un quinto de los consejeros, incluyendo en el orden del día las cuestiones solicitadas.

8. Las sesiones del consejo y de las Comisiones serán públicas, salvo los casos previstos por el Reglamento.

\section{Art. 32 (Competencias de los Consejos)}

1. El Consejo es el órgano de dirección y de control político-administrativo.

2. El Consejo tiene competencia limitada a los siguientes actos fundamentales:

a) los estatutos del ente $y$ de los organismos especiales, los reglamentos, el ordenamiento de las dependencias y de los servicios;

b) los programas. las memorias de previsión y programáticas, los planes financieros y los programas de obras públicas, el presupuesto anual y plurianual y sus modificaciones respectivas, la liquidación del prepuesto, los planes territoriales y urbanísticos, los programas anuales y plurianuales para su ejecución, sus eventuales modificaciones, los informes que se emitan sobre dichas materias;

c) la regulación del estatuto jurídico y de la sección personal; la plantilla orgánica y sus variaciones correspondientes.

d) los convenios entre municipios y aquéllos entre municipios y provincias, la constitución y la modificación de formas asociativas;

e) los establecimientos, las funciones y las normas sobre el funcionamiento de los organismos de descentralización y partición; 
f) la gestión directa de los servicios públicos, la constitución de establecimientos y de organismos autónomos, la concesión de los servicios públicos, la participación del ente local en sociedades de capital, el arrendamiento de actividades o servicios mediante convenios;

g) la imposición y ordenación de los tributos, la regulación general de las tarifas por el disfrute de bienes y servicios;

h) las directrices que deban observar los organismos públicos $y$ sus entes dependientes, subvencionados o sujetos a control;

i) la concertación de préstamos y la emisión de empréstitos por obligaciones;

1) los gastos que agraven el presupuesto durante varios ejercicios sucesivos, excluidos aquéllos relativos al alquiler de inmuebles $y$ al suministro $y$ abastecimiento de bienes $y$ servicios de carácter continúo;

$\mathrm{m})$ las adquisiciones y enajenaciones inmobiliarias, las correspondientes permutas, los arriendos y las concesiones que no estén previstas expresamente en actos fundamentales del Consejo o que no sean mera administración ordinaria de funciones y servicios de competencia de la Junta, del Secretario o de otros funcionarios;

n) el nombramiento, designación y cese de sus representantes ante entes, organismos y establecimientos que actúen en el ámbito del municipio o de la provincia o sean dependientes o controlados por ellos. Los nombramientos y las designaciones deberán efectuarse en el plazo de cuarenta y cinco días desde la elección de la Junta o antes del plazo de vencimiento del anterior mandato. En caso de falta de acuerdo si procederá según lo previsto en al art. 36, párrafo quinto.

3. Los acuerdos relativos a los asuntos previstos en el presente artículo no podrán ser adoptados por vía de urgencia por otros órganos del municipio o de la provincia, salvo aquellos relativos a las modificaciones del presupuesto que deberán someterse a la ratificación del Consejo en los sesenta días siguientes, bajo sanción de caducidad.

\section{Art. 33 (Composición de la Junta)}

1. La junta municipal está integrada por el Alcalde, que la preside, y por un número par de asesores, fijado por el estatuto, no superior a cuatro para los municipios con población inferior a 3.000 habitantes, no superior a seis para los municipios con población entre 3.000 y 30.000 habitantes, no superior a ocho para los municipios con 
población entre 30.001 y 100.000 habitantes o capital de provincia, no superior a doce para los municipios entre 100.001 y 500.000 habitantes, no superior a dieciséis para los municipios con más de 500.000 habitantes.

2. La Junta provincial estará integrada por el Presidente, que la preside, y por un número para de consejeros, fijado por el estatuto, no superior a un quinto del número legal de los consejeros del ente, con redondeo a la unidad por exceso a fin de obtener un número par $y$, en todo caso, no superior a ocho.

3. Con derogación de los establecido en el párrafo 1 del art. 34, el estatuto podrá prever la elección como asesores de ciudadanos que no pertenezcan al Consejo, que reúnan los requisitos de compatibilidad para el cargo de consejero.

\section{Art. 34 (Elección del Alcalde, del Presidente de la provincia y de la Junta)}

1. El Alcalde, el Presidente de la provincia y la Junta municipal y provincial serán elegidos por el respectivo Consejo de entre sus miembros en la primera sesión, inmediatamente después de que sean convalidados los efectos, según las modalidades fijadas por la presente ley y por el estatuto.

2. Dicha elección tendrá lugar, en todo caso, en el plazo de sesenta dias desde la proclamación de los electos o desde la fecha en la que se haya verificado la vacante, o en caso de dimisión, desde la fecha de presentación de la misma.

3. Le elección tendrá lugar sobre la base de un documento programático, suscrito por al menos un tercio del número legal de consejeros del municipio o de la provincia, que contenga la lista de los candidatos al cargo de Alcalde o de Presidente de la provincia y de los consejeros, seguida de un debate sobre el programa expuesto por el candidato al cargo de Alcalde o de Presidente de la provincia.

4. La elección tendrá lugar mediante escrutinio público por mayoría absoluta del número legal de consejeros. Con tal objeto, se realizarán tres sucesivas votaciones, a celebrarse en distintas sesiones dentro del plazo previsto en el párrafo 2. Cuando en ninguna de ellas se alcance la mayoría citada, el Consejo será disuelto a tenor del art. 39 , párrafo 1 , letra b), número 1).

5. El consejero de mayor edad convocará los Consejos municipales y provinciales para la elección del Alcalde, del Presidente de la provincia y de las Juntas municipales y provinciales. La primera convocatoria deberá efectuarse en los diez dias siguientes a la proclamación de los electos o desde la fecha en la que se haya producido la vacante. 
6. El consejero de mayor edad presidirá las sesiones previstas en el párrafo precedente.

7. Los acuerdos de nombramiento del Alcalde, del Presidente de la provincia y de la junta serán ejecutivos a los tres días del envío al órgano regional de control, cuando no se produzca la anulación por vicio de legalidad.

8. La dimisión del Alcalde o del Presidente de la provincia o de más de la mitad de los consejeros conlleva el cese de la respectiva Junta.

\section{Art. 35 (Competencias de la Junta)}

Corresponde a la Junta resolver todos los actos de administración que no estén reservados por las leyes al consejo y que no sean competencia, previstas por las leyes o por el Estatuto, del Alcalde o del Presidente de la provincia, de los órganos de descentralización, de Secretario o de los funcionarios dirigentes; dará cuenta anualmente al Consejo de su actividad propia, ejecutará las directivas generales de éste y desarrollará la actividad de propuesta y de impulso en relación al mismo.

\section{Art. 36 (Competencias del Alcalde y del Presidente de la pro- vincia)}

1. El Alcalde y el Presidente de la provincia representan al ente, convocan y presiden el Consejo y la Junta, vigilan el funcionamiento de los servicios y de las dependencias asi como la ejecución de sus actos.

2. Ejercen las funciones que les atribuyan las leyes, el estatuto y los reglamentos y vigilan el cumplimiento de las funciones estatales y regionales atribuidas o delegadas al municipio o a la provincia.

3. El Alcalde es, además, competente, en el ámbito de la normativa regional y de acuerdo con las directrices expresadas del Consejo municipal, para coordinar los horarios de las actividades comerciales, de los servicios públicos, así como los horarios de apertura al público de las dependencias periféricas de las Administraciones públicas (14), con el fin de armonizar el desarrollo de los servicios a las necesidades globales y generales de los usuarios.

4. En caso de incumplimiento de la obligación de convocar al Consejo, el Prefecto, previo requerimiento, lo convocará de oficio.

(14) Parece que ha de entenderse que esta facultad del Alcalde en cuanto a la fijación de horarios de apertura al público "degli uffici periferici delle amministrazioni pubbliche" ha de referirse a las oficinas municipales descentralizadas. 
5. Cuando el Consejo no acuerde los nombramientos de su competencia en el plazo previsto en el art. 32, párrafo 2, letra n) o, en todo caso, antes de sesenta días desde la primera inclusión en el orden del día, el Alcalde o el Presidente de la Provincia, oídos los portavoces de los consejeros, antes de quince días desde que finaliza el plazo, procederá a los nombramientos mediante decreto, comunicando al Consejo en la primera sesión, EN caso de que no se llegue a decisión alguna, el Comité Regional de Control adoptará, en el plazo perentorio de los sesenta días siguientes, la resolución sustitutiva prevista en el art. 48.

6. El Alcalde y el Presidente de la provincia, antes de asumir las funciones, prestarán juramento ante le Prefecto según la fórmula prevista en el art 11. del Texto Unico de las disposiciones relativas al estatuto de los empleados civiles del Estado, aprobado por Decreto del Presidente de la República, de 10 de enero de 1957, $n^{\circ} 3$.

7. La faja tricolor con el escudo de la República es el distintivo del Alcalde, que se llevará cruzada sobre el hombro derecho.

\section{Art. 37 (Moción de censura constructiva, revocación y sustitución)}

1. El voto del Consejero contrario a una propuesta de la Junta no conllevará el cese de ésta.

2. El Alcalde, el Presidente de la provincia y la Junta cesarán en su cargo en caos de aprobación de una moción de censura constructiva adoptada mediante votación nominal con el voto de la mayoría absoluta del número legal de consejeros del municipio o de la provincia.

3. La moción deberá ser suscrita por al menos un tercio de los consejeros y sólo podrá presentarse contra la totalidad de la Junta; deberá contener la propuesta de nuevas líneas político-administrativas; de un nuevo Alcalde o Presidente de la provincia y de una nueva Junta de conformidad a lo previsto en el art. 34 .

4. La moción será debatida no antes de cinco días y no más tarde diez días desde su presentación.

5. La aprobación de la moción de censura conllevará la proclamación del nuevo propuesto.

6. El Consejo procederá, en la misma sesión, a propuesta del alcalde o del Presidente, a la sustitución de cada uno de los miembros de la Junta cesante, revocados por el Consejo a propuesta del Alcalde o del Presidente de la provincia, o cesados en el cargo por otra causa.

7. El cese previsto en el párrafo 8 del art. 34 se producirá por la elección de la nueva Junta. 
8. El estatuto podrá prever, en las formas indicadas en el presente artículo, la revocación o la censura constructiva de los cargos electos de los Consejos municipales y provinciales, de los organismos autónomos y de los establecimientos dependientes.

\section{Art. 38 (Atribuciones del Alcalde en los servicios de competen- cia estatal)}

1. El Alcalde, como delegado del Gobierno es responsable:

a) de la custodia del Registro del Estado Civil y de población y al cumplimiento de cuanto le sea encomendado por las leyes en materia electoral, reclutamiento militar y estadística;

b) de dictar los actos que le atribuyan las leyes y los reglamentos en materia de orden y seguridad pública, de sanidad y de higiene pública;

c) de la ejecución de las funciones que le confíen las leyes, en materia de seguridad pública y de policía judicial.

d) de la vigilancia en todo lo que pueda interesar la seguridad y el orden público, dando cuenta de ello al Prefecto.

2. El Alcalde, como delegado del Gobierno, adoptará, por acto motivado y con respeto de los principios generales del ordenamiento jurídico, resoluciones coyunturales y urgentes en materia de sanidad e higiene construcción y policía local con el fin de prevenir y eliminar graves peligros que amenacen la integridad de los ciudadanos; para la ejecución de las correspondientes órdenes puede solicitar al Prefecto, cuando sea necesario, el auxilio de la fuerza pública.

3. Si el decreto (15), adoptado a tenor del párrafo 2, está dirigido a personas determinadas y éstas no ejecutan la orden dada, el Alcalde podrá proceder de oficio a costa de los interesado, sin prejuicio de la acción penal por los delitos en los que hubieran incurrido.

4. Quien sustituya al Alcalde ejercerá también las funciones previstas en el presente artículo.

5. En el ámbito de los servicios previstos en el presente artículo, el Prefecto podrá ordenar inspecciones para comprobar el funcionamiento regular de dichos servicios, así como para la obtención de datos e informaciones que afecten a otros servicios de carácter general.

6. En las materias previstas en las letras a), b), c) y d) del párrafo 1, asi como en el art. 10, el Alcalde, previa comunicación al Prefecto, podrá delegar el ejercicio de las funciones alli enumeradas al Presidente del Consejo circunscripcional; el Alcalde podrá conferir la delegación a un consejero municipal para el ejercicio de las funciones en

(15) Traduzco "ordinanza" en este contexto por "decreto". 
los barrios y en los distritos si no están constituidos los órganos de descentralización municipal.

7. El Prefecto, si el Alcalde o quien ejercite sus funciones no cumple con las obligaciones previstas en el presente artículo, podrá nombrar un Comisario para el cumplimiento de dichas funciones.

8. El ente afectado correrá con los gastos del Comisario.

9. Si el Alcalde no adopta las resoluciones previstas en el párrafo 2, lo hará el Prefecto por Decreto.

\section{CAPITULO XI}

\section{CONTROL SOBRE LOS ORGANOS}

\section{Art. 39 (Disolución y suspensión de los Consejos municipales y provinciales)}

1. El Presidente de la República, a propuesta del Ministro del Interior podrá disolver los Consejos municipales y provinciales.

a) cuando realicen actos contrarios a la Constitución y por graves y persistentes violaciones de las leyes, así como por graves motivos de orden público;

b) cuando no pueda asegurarse el normal funcionamiento de los órganos y de los servicios por las siguientes causas:

1) falta de elección del Alcalde, del Presidente de la Administración provincial y de la Junta en el Plazo de sesenta días desde la proclamación de los electos o de la vacante de cualquier modo verificada, o en caso de dimisión, desde la fecha de presentación de la misma;

2) dimisión o cese de al menos la mitad de los consejeros;

c) cuando el presupuesto no sea aprobado dentro de plazo.

2. En el supuesto previsto en la letra c), del párrafo 1, transcurrido el plazo en el que debe aprobarse el presupuesto sin que la Junta haya preparado el correspondiente proyecto, el órgano regional de control nombrará un comisario con el objeto de que lo prepare de oficio para someterlo al Consejo. En tal caso y, siempre que el Consejo no haya aprobado en los plazos legales el proyecto de presupuesto preparado por la Junta, el órgano regional de control, señalará al Consejo, mediante carta notificada a cada una de los consejeros, un plazo no superior a veinte días para su aprobación, transcurrido el cual sustituirá, mediante al oportuno Comisario, a la Administración incumplidora. De la resolución sustitutiva se dará cuenta al Prefecto que iniciará el procedimiento para la disolución del Consejo. 
3. El Decreto de disolución nombrará un Comisario que ejercerá las atribuciones que le confiera dicho Decreto.

4. La renovación del Consejo en los supuestos de disolución debe tener lugar en el plazo de noventa dias desde la publicación del respectivo Decreto. Dicho plazo podrá prorrogarse por no más de noventa días al solo objeto de hacer coincidir las elecciones con el primer turno electoral útil previsto por la ley.

5. Los consejeros cesado en el cargo como consecuencia de la disolución continuarán ejerciendo los cargos externos que eventualmente tengan atribuidos, hasta el nombramiento de sus sucesores.

6. Al Decreto de disolución de acompañará la exposición del Ministro que contenga los motivos de la decisión; la aprobación del Decreto de disolución se comunicará inmediatamente al Parlamento. El Decreto se publicará en la Gaceta Oficial de la República italiana.

7. Iniciado el procedimiento previsto en los párrafos precedentes, el Prefecto, por motivos de grave y urgente necesidad, podrá suspender, por un período nunca superior a noventa días, los Consejos municipales y provinciales y nombrará un comisario para la administración provisional del ente.

8. En tal caso, los plazos previstos en el párrafo 4, se computarán desde la fecha de la resolución de suspensión.

\section{Art. 40 (Destitución y suspensión de las autoridades de los en- tes locales)}

1. Por Decreto del Presente de la República, a propuesta del Ministro del Interior, el Alcalde, el Presidente de la provincia, los presidentes de los consorcios y de las Juntas, los presidentes de los Consejos circunscripcionales podrán ser destituidos cuando realicen actos contrarios a la Constitución o por graves y persistentes violaciones de la ley o cuando fueren inculpados por alguno de los delitos previstos en la ley de 13 de septiembre de 1982, no 646, y sucesivas modificaciones y desarrollos, o sometidos a medida de prevención $o$ de seguridad.

2. A la espera del Decreto, el Prefecto podrá suspender a las autoridades previstas en el párrafo 1 cuando subsistan motivos de grave y urgente necesidad.

3. Quedan a salvo las disposiciones dictadas por el art. 15 de la ley de 19 de marzo de 1990, no 55 . 


\section{CAPITULO XII}

CONTROL SOBRE LOS ACTOS

\section{Art. 41 (Comité Regional de Control)}

1. Para el ejercicio del control de legalidad previsto en el art. 130 de la Constitución, se creará, por Decreto del Presidente de la Junta Regional, el Comité Regional de Control de los actos de los municipios y de las provincias.

2. Las leyes regionales podrán organizar el Comité en secciones territoriales o por materias, salvaguardando mediante las medidas oportuna la unidad de dirección.

3. Con tal objeto, las Regiones, en colaboración con los servicios del Comité, cuidarán de la publicación periódica de las principales decisiones del Comité Regional de Control con las respectivas motivaciones de referencia.

\section{Art. 42 (Composición del Comité)}

1. El Comité regional de Control y cualesquiera de sus eventuales secciones estarán integrados:

a) por cuatro expertos nombrados por el Consejo Regional, de ellos:

1) uno matriculado desde al menos diez años en el Colegio de Abogados, elegido entre una terna propuesta por el Colegio profesional competente;

2) uno matriculado desde al menos diez años en el Colegio de Doctores mercantilistas o de Contables, elegido entre una terna propuesta por los respectivos Colegios profesionales;

3) uno elegido entre quienes hayan desempeñado al menos durante cinco años completos el cargo de Alcalde, de Presidente de la provincia, de Consejero regional o de parlamentario nacional, o entre funcionarios estatales, regionales o de los entes jubilados, de categoría no inferior a Directores de Servicios (16) o equipados;

4) uno elegido entre los magistrados o abogados del Estado jubilados, o entre profesores de carrera de universidad en materias jurídicas y administrativas o entre secretarios municipales o provinciales jubilados;

(16) Traduzco "dirigenti" en el contexto de la organización administrativa municipal como "Directores de servicio", en cuanto Jefes de Servicio o Negociado. 
b) por un experto nombrado por el Comisario del Gobierno elegido entre los funcionarios de la Administración civil del Ministerio del Interior destinado en la respectiva provincia

2. El Consejo Regional nombrará no más de dos miembros suplentes que reúnan los requisitos en la letra a) párrafo 1; el Comisario del Gobierno nombrará un tercio de los suplentes, que reúnan los requisitos previstos en la letra b) del párrafo 1.

3. En caso de ausencia o impedimento de los miembros titulares, previstos respectivamente en las letras a) y b) del párrafo 1 , intervendrán en las sesiones los miembros suplentes, elegidos o designados de la misma categoría.

4. El Comité y cualesquiera de sus Secciones elegirán entre sus miembros el Presidente y un Vicepresidente, elegidos entre los miembros nombrados por el Consejo Regional.

5. Actúa de Secretario un funcionario de la Región.

6. Los comités y las Secciones se renovarán en su totalidad tras las nuevas elecciones del Consejo Regional, asi como cuando cese simultáneamente la mayoría de los respectivos miembros.

7. El Presidente y el Vicepresidente del Comité, si son empleados públicos, quedarán en excedencia (17); si son empleados privados quedarán en expectativa no retribuida.

8. A los miembros del Comité se les aplica las normas relativas a las licencias y a las expectativas previstas para las autoridades locales.

\section{Art. 43 (Incompatibilidad e inegibilidad)}

1. No podrán ser nombrados y no pueden formar parte de los Comités Regionales de Control:

a) los parlamentarios nacionales y europeos;

b) los miembros del Consejo Regional;

c) las autoridades de los municipios o provincias o de otros entes sujetos a control del Comité, asi como aquéllos que hayan desempeñado tales cargos en el año anterior a la constitución del Comité mismo;

d) aquéllos que se hallen en la condición de inelegibilidad a los cargos previstos en las letras b) y c), con exclusión de los magistrados y de los funcionarios del Estado;

e) los empleados y los contables de la Región y de los entes locales sujetos al control del Comité así como los empleados de los partidos presentes en los Consejos de los entes locales de la Región;

(17) Traduzco "fuori ruolo" por nuestra situación administrativa de "excedencia". 
f) los miembros de otro Comité Regional de Control o de sus Secciones.

g) aquellos que presten actividad de consulta o de colaboración para la Región o entes sometidos al control regional;

h) aquellos que ostenten cargos directivos o ejecutivos en los partidos a nivel provincial, regional o nacional, así como aquéllos que hayan desempeñado tales cargos el año anterior a la constitución del Comité.

\section{Art. 44 (Normas regionales)}

1. Las leyes regionales regularán el funcionamiento de los Comités Regionales de Control y de sus Secciones, las retribuciones que correspondan a sus miembros, las funciones del Presidente $y$ del $\mathrm{Vi}$ cepresidente, las formas de publicidad de la actividad de los Comités y de consulta de las decisiones, así como la expedición de copias de mismas.

2. Las leyes regionales dictarán las normas para la elección, por mayoría cualificada, de los miembros del Comité Regional de Control y para la oportuna sustitución de los mismos en caso de muerte, dimisión, cese por reiteradas ausencias injustificadas o incompatibilidad sobrevenida, así como para la suplencia del Presidente.

3. Los gastos para el funcionamiento de los Comité Regionales de Control y de sus servicios, así como el pago de las retribuciones por el cargo de los miembros, correrá a cargo de la Región.

4. Las Regiones organizarán las estructuras al servicio del Comité Regional de Control inspirándose en los principios de la adecuación funcional y de la autonomía del órgano.

\section{Art. 45 (Acuerdos sujetos al control preventivo de legalidad)}

1. Están sujetos al control preventivo de legalidad los acuerdos que la ley reserva a los Consejos y las juntas, por propia iniciativa, deciden someter al Comité.

2. Los acuerdos de competencia de las Juntas en las materias más abajo enumeradas, serán sometidas el control en los límites de la ilegalidad denunciada, cuando un tercio de los consejeros provinciales o un tercio de los consejeros en los municipios en los que se vota por el sistema proporcional o un quinto de los consejeros en los municipios en los que se vota por el sistema mayoritario, los impugnen por escrito y motivadamente con indicación de las normas violadas en el plazo de diez dias desde la publicación en el tablón de edictos: 
a) adquisiciones, enajenaciones, arrendamientos y en general todos los contratos;

b) ayudas, retribuciones, indemnizaciones, reembolsos y exenciones a las autoridades, empleados o a terceros;

c) selección, estatuto jurídico y retribuciones del personal.

3. Los acuerdos previstos en el párrafo 2 , simultáneamente a la publicación en el Tablón de edictos, se comunicarán a los portavoces de los grupos municipales y provinciales (18).

4. Los acuerdos de la Junta podrán también someterse a control, en los mismos plazos previstos en el párrafo 2, cuando un tercio de los consejeros provinciales o un tercio de los consejeros en los municipios en los que se vota mediante el sistema proporcional a un quinto de los consejeros en los municipios en los que se vota mediante el sistema mayoritario, mediante impugnación escrita y motivada, los consideren viciados de incompetencia o contrarios a actos fundamentales del Consejo.

5. No estarán sujetos al control preventivo de legalidad los acuerdos meramente ejecutivos de otros acuerdos.

\section{Art. 46 (Modalidades de control preventivo de legalidad de los actos y del presupuesto)}

1. Salvo lo dispuesto en los artículos siguientes, los acuerdos enumerados en el art. 45 serán ejecutivos si, en el plazo de veinte días desde su recepción, el Comité Regional de Control no adopta una resolución de anulación, dando cuenta de ella, en idéntico plazo, al ente interesado.

2. El control de legalidad se limitará a la verificación de la conformidad del acto a las normas vigentes así como a las normas estatutarias del ente, excluida cualquier valoración distinta del interés público perseguido.

3. La resolución de anulación indicará las normas violadas, incluso con referencia a los principios generales del ordenamiento jurídico.

4. El plazo quedará interrumpido por una sola vez si antes de su vencimiento, el Comité Regional de Control solicita aclaraciones o datos que completen su juicio al ente autor del acuerdo. En eses caso, el plazo para la anulación comienza a contarse desde el momento de la recepción de los datos solicitados.

5. Los acuerdos serán ejecutivos antes del transcurso del plazo, si el Comité Regional de Control comunica no haber encontrado vicios de legalidad.

(18) Traduzco "capigruppo consiliari" por "portavoces de los grupos (políticos) municipales y provinciales". 
6. El envío al órgano de control de los acuerdos declarados urgentes tendrá lugar en el plazo de cinco dias desde la adopción, bajo sanción de caducidad.

7. Las leyes regionales establecerán las modalidades y los plazos para el envío de los acuerdos al órgano de control y regulará el vencimiento de los plazos que tiene el Comité Regional para el ejercicio del control.

8. El plazo para el examen del presupuesto y de la liquidación del presupuesto por el Comité de Control será de cuarenta dias. El transcurso del plazo determina la ejecutividad de los acuerdos, con arreglo a lo previsto en el párrafo 1.

9. El Comité de Control podrá señalar al ente interesado las modificaciones a incluir en las modificaciones a incluir en las resultas de la liquidación del presupuesto, con invitación para que las apruebe en el plazo máximo de treinta dias.

10. En caso de falta de aprobación de la liquidación del presupuesto en el plazo legal, de falta de aprobación de sus modificaciones en el plazo previsto en el párrafo 9 o de anulación de los acuerdos de aprobación de la liquidación del presupuesto por el Comité de Control, éste procederá al nombramiento de uno o más Comisarios para la elaboración de dicha liquidación.

11. En el examen del presupuesto y de la liquidación del presupuesto, el control de legalidad se extenderá a la coherencia interna de los actos y a la correspondencia de los datos contables con los del acuerdo, así como con los documentos justificativos anexos a los mismos.

\section{Art. 47 (Publicación y ejecutividad de los acuerdos)}

1. Todos los acuerdos municipales y provinciales serán publicados mediante exposición en el tablón de edictos, en la sede del ente, durante quince días consecutivos, salvo disposición específica de las leyes.

2. Los acuerdos no sujetos al control preventivo de legalidad serán ejecutivos a los diez días de su publicación.

3. En caso de urgencia, los acuerdos del Consejo y de la Junta podrán ser declarados inmediatamente ejecutivos con el voto expreso de la mayoría de los miembros.

\section{Art. 48 (Poder sustitutivo)}

1. Cuando los municipios y las provincias, pese a ser requeridos para actuar dentro de los oportunos plazos, retrasen u omitan el cumplimiento 
de actos declarados obligatorios por ley, el Comité Regional de Control procederá por medio de un Comisario. Plazo fijado no podrá ser inferior a treinta días, salvo resolución motivada en los casos de urgencia.

2. Las modalidades de ejercicio de la facultad prevista en el párrafo 1 serán reguladas por las leyes regionales.

\title{
Art. 49 (Control y vigilancia respecto de los entes distintos de los municipios y de las provincias)
}

Las normas sobre control y sobre fiscalización dictadas para los municipios y para las provincias se aplicarán a las Unidades Sanitarias Locales, a los Consorcios, a las Uniones de municipios y a las Comunidades de montaña, salvo disposición contraria prevista por las leyes vigentes.

\section{Art. 50 (Informes obligatorios)}

1. Los informes obligatorios de la Administración estatal, incluso de ordenamiento autónomo, de las regiones y de cualquier otro ente sujeto a tutela estatal, regional y subregional, previstos en cualquier norma que tenga fuerza de ley, relativa a la programación, planteamiento y ejecución de obras públicas o de otras actividades de los entes locales, serán emitidos dentro del plazo de sesenta días desde la solicitud, siempre que la ley no prescriba un plazo menor.

2. El plazo, previa comunicación motivada al ente local interesado por parte de la Administración llamada a emitir el informe, será prorrogado por un tiempo igual a aquel plazo originario.

3. Transcurrido infructuosamente el plazo originario, o el plazo prorrogado, se prescindirá del informe.

\author{
CAPITULO XIII \\ DEPENDENCIAS Y PERSONAL
}

\section{Art. 51 (Organización de las dependencias y del personal)}

1. Los municipios y las provincias regularán los oportunos reglamentos la dotación del personal y, de conformidad con el estatuto, la organización de las dependencias y de los servicios, con arreglo a criterios de autonomía, funcionalidad y economía de gestión y según principios de profesionalidad y responsabilidad. El reglamento regulará las atribuciones de los Directores de Servi- 
cio con responsabilidad gestora para la ejecución de los objetivos fijados por los órganos del ente y establecerá las modalidades de la actividad de coordinación entre el secretario del ente y aquéllos.

2. Corresponde a los Directores de Servicio la dirección de las dependencias y de los servicios según los criterios y las normas dictadas por los estatutos y los reglamentos, y se adecuarán al principio según el cual los poderes de dirección y de control corresponderán a los órganos electivos mientras que la gestión administrativa se atribuirá a los Directores de servicio.

3. Corresponden a los Directores de servicio todas las funciones, incluida la aprobación de actos que comprometan a la Administración hacia el exterior, que la ley y el estatuto no reserven expresamente a los órganos de gobierno del ente. Les corresponde en particular, según las modalidades establecidas por el estatuto, la presidencia de las comisiones de selección y concurso, la responsabilidad sobre los procedimientos de adjudicación y de concurso, y la firma (19) de los contratos.

4. Los Directores de servicio serán directamente responsables, en relación con los objetivos del ente, de la corrección administrativa y de la eficiencia de gestión.

5. El estatuto podrá prever que la cobertura de los puestos de responsables de los servicios o de las dependencias, de categorías directivas 0 de alta especialización, pueda tener lugar mediante contrato a tiempo determinado de Derecho público o, excepcionalmente y mediante acuerdo motivado, de Derecho privado, sin prejuicio de los requisitos requeridos de la calificación a cubrir.

6. Los cargos de dirección de áreas funcionales podrán ser conferidas por tiempo determinado, mediante las modalidades y según los plazos fijado por el estatuto. Se dispondrá su renovación mediante resolución motivada que hará referencia a la valoración de los resultados obtenidos por el Director de servicio en el periodo concluido, en relación a la consecución de los objetivos y a la ejecución de los programas, así como en relación al nivel de eficiencia y de eficacia alcanzado por los servicios del ente dirigidos por él. Podrá disponerse la interrupción anticipadas del cargo mediante resolución motivada, cuando el nivel de los resultados conseguidos por el Director de Servicio resulte inadecuado. El nombramiento como cargo directivo conlleva la atribución de una retribución económica complementaria que cesará con la finalización o interrupción del cargo.

(19) Traduzco "stipulazione dei contratti" en este contexto por "la firma de los contratos" 
7. Para objetivos determinados y para contratos a tiempo determinado el reglamento podrá autorizar colaboraciones externas de lato contenido profesional.

8. El estatuto jurídico y la retribución económica de los empleados de los entes locales será regulado mediante acuerdos colectivos nacionales de duración trienal hechos ejecutivos mediante Decreto del Presidente de la República según el procedimiento previsto en el artículo 6 de la ley de 29 de marzo de 1983, no 93. En todo caso queda reservada a la ley la regulación del acceso a la relación de empleo público, de las causas de cese del mismo y de las garantías del personal en orden al ejercicio de los derechos fundamentales. En al ámbito de los principios establecidos por la ley, queda además reservado a los actos normativos de los entes, según los respectivos ordenamientos, la regulación relativa a las modalidades de obtención de la titularidad de los cargos así como la determinación y la valoración de la totalidad de las plantillas orgánicas.

9. La responsabilidad, las sanciones disciplinarias, el procedimiento respectivo, la destitución de oficio y la readmisión al servicio serán regulados según las normas previstas para los empleados civiles del Estado.

10. Se creará en cada ente una Comisión de Disciplina, integrada por el jefe de la Administración o un delegado suyo, que la presidirá. por el Secretario del Ente y por un empleado designado al inicio de cada año por el personal del ente según las modalidades establecidas por el reglamento.

11. Las normas del presente artículo se aplicarán también a las dependencias y al personal de los entes dependientes, de los consorcios y de las comunidades de montaña, salvo lo previsto en sentido contrario por la ley.

\section{Art. 52 (Secretario municipal)}

1. El municipio y la provincia tendrá un Secretario titular, funcionario estatal, inscrito en el correspondiente Registro nacional organizado territorialmente.

2. La ley regulará la creación del Registro y los requisitos profesionales para la inscripción, la clasificación de los entes y la retribución económica, las atribuciones y la responsabilidad, los traspasos y los procedimientos disciplinarios, las modalidades de acceso y ascenso en la carrera, así como el organismo colegiado, organizado territorialmente, presidido por el Ministros del Interior o un Delegado suyo e integrado paritariamente por representantes de los entes locales, del Ministerio de Interior y de los Secretarios, encargado de llevar el 
Registro y ejercer las funciones de dirección y de administración de los secretarios municipales y provinciales. La ley regulará, además, las modalidades de participación de los entes locales en el nombramiento y en la destitución del secretario entre los inscritos en el Registro previsto en el párrafo 1.

3. El Secretario, respetando las directrices que le haya impartido el Alcalde o el Presidente de la provincia del que depende funcionalmente, además de las competencias previstas en el art. 51, supervisará el cumplimiento de las funciones de los Directores de servicio y coordinará su actividad, cuidará de la ejecución de los derechos, será responsable de la instrucción de los acuerdos, procederá a su ejecución y participará en las reuniones de la Junta y del Consejo.

4. El estatuto y el reglamento podrán crear un Vicesecretario para el desempeño de funciones vicarias del Secretario, su asistencia o sustitución en los casos de vacante, ausencia o impedimento.

\section{Art. 53 (Responsabilidad del Secretario de los entes locales y de los Directores de servicios)}

1. Deberá solicitarse informe de todo presupuesto de acuerdo que se someta a la Junta y al Consejo, exclusivamente en cuanto a su regularidad técnica y contable, al responsable del servicio interesado y al responsable de contabilidad, así como al Secretario municipal o provincial en cuanto a la legalidad. Los informes se unirán al acuerdo.

2. Si el ente no tuviera funcionarios responsables de los servicios, el informe será emitido por el Secretario municipal o provincial en cuanto a la legalidad. Los informes se unirán al acuerdo.

3. Los sujetos previstos en el párrafo 1 , responderán en vía administrativa y contable de los informes emitidos.

4. Los Secretarios municipales y provinciales serán responsables de los actos y de los procedimientos aplicativos de los acuerdos previstos en el párrafo 1 , junto con el funcionario encargado.

\section{CAPITULO XIV}

HACIENDA Y CONTABILIDAD

\section{Art. 54 (Hacienda local)}

1. Se regulará por ley el ordenamiento de la hacienda local. 
2. La ley reconocerá a los municipios y a las provincias, en el ámbito de la hacienda pública, autonomía financiera fundada en la certeza de los recursos propios y transferidos.

3. La ley reconocerá, además, a los entes locales la potestad tributaria autónoma en materia de impuestos, tasas y tarifas, con la consiguiente adecuación de la legislación tributaria vigente.

4. La hacienda de los municipios y de las provincias está constituida por:

a) impuestos propios;

b) recargos o participación en los impuestos estatales o regionales;

c) tasas y derechos por servicios públicos;

d) transferencias estatales (20);

e) transferencias regionales;

f) otros ingresos propios, incluidos los de naturaleza patrimonial;

g) recursos para inversiones;

h) otros ingresos

5. Las transferencias estatales deberán garantizar los servicios locales indispensables y se distribuirán con arreglo a criterios objetivos que tengan en cuenta la población, el territorio y las condiciones socioeconómicas, así como a una equilibrada distribución de los recursos que tenga en cuenta los desequilibrios de la fiscalidad local.

6. El Estado destinará ayudas específicas para afrontar situaciones excepcionales.

7. Los ingresos fiscales financiarán los servicios públicos considerados necesarios para el desarrollo de la comunidad e incluirán las transferencias estatales para el establecimiento de los servicios públicos indispensables.

8. A todo ente local le corresponden las tasas, derechos, tarifas y contraprestaciones (21) por los servicios de su competencia. Los Entes locales fijarán para los servicios públicos tarifas o precios a cargo de los usuarios, aunque no estén generalizados. El estado y las regiones, cuando prevean por ley supuestos de gratuidad en los servicios de competencia de los municipios y provincias o fijen precios y tarifas inferiores al coste efectivo de la presentación, deberán garantizar a los entes locales recursos financieros compensatorios.

9. La ley creará un Fondo nacional ordinario para contribuir a las inversiones de los entes locales destinadas a la realización de obras públicas de preeminente interés social y económico.

(20) Traduzco "tranferimenti erariali" por "transferencias estatales".

(21) Traduzco "corrispettivi" en este contexto por "contraprestaciones" en el sentido de cantidad satisfecha. 
10. La ley creará un Fondo nacional especial para financiar con criterios de perecuación respecto de las inversiones destinadas a la realización de obras públicas únicamente en áreas o para situaciones determinadas por la ley estatal.

11. El importe total de las transferencias y de los fondos será determinado con arreglo a parámetro fijados por la ley para cada uno de los años previsto en el presupuesto plurianual del Estado y no podrá disminuirse durante el trienio.

12. Las Regiones cooperarán a la financiación de los entes locales mediante la elaboración del plan regional de desarrollo y de los programas de inversión, garantizando la cobertura financiera de las cargas necesarias para el ejercicio de las funciones transferidas o delegadas.

13. Los recursos correspondientes a municipios y provincias para gastos de inversión previstos en leyes sectoriales del Estado se distribuirán con arreglo a programas regionales. Las Regiones, además, determinarán mediante ley la financiación de las competencias que atribuyan a los entes locales en función del coste de gestión de los servicios en el marco de la programación regional.

\section{Art. 55 (Presupuesto y programación financiera)}

1. El ordenamiento financiero y contable de los entes locales se regulará por ley del Estado.

2. Los municipios y las provincias aprobarán antes del 31 de octubre el presupuesto para el año siguiente, respetando los principios de universalidad, de integridad y de equilibrios económico y financiero.

3. Al presupuesto se unirá una memorial de previsión y programática y un presupuesto plurianual de duración igual al de la Región a la que pertenezca.

4. El presupuesto y sus anexos deberán, en todo caso, redactarse de manera que permitan la lectura por programas, servicios y actuaciones.

5. No podrán asumirse compromisos de gasto sin certificación de la respectiva cobertura financiera por parte del responsable del servicio financiero. Sin tal certificación el acto será nulo de pleno derecho.

6. Los resultados de gestión se anotará mediante contabilidad económica y justificarán mediante la rendición de cuentas comprensiva de la cuenta del presupuesto y de la cuenta del patrimonio.

7. La junta unirá a la liquidación del presupuesto una memoria aclarativa que exprese la valoración de eficacia de la acción realizada en función de los resultados conseguidos en relación a los programas y a los costes soportados. 
8. El Consejo aprobará la liquidación del presupuesto antes del 30 de junio del año siguiente.

\section{Art. 56 (Acuerdos sobre contratación y procedimiento respectivo)}

1. La estipulación de los contratos deberá ser precedida de los oportunos acuerdos señalando:

a) los fines que con el contrato se pretende alcanzar;

b) el objeto del contrato, su forma y las cláusulas consideradas esenciales;

c) las modalidades de selección del contratista admitidas por las disposiciones vigentes en materia de contratos de la Administración del Estado y las razones que están en sus base.

2. Los entes locales se atenderán al procedimiento provisto por la normativa de la Comunidad Económica Europea incorporando o, en todo caso, vigente en el ordenamiento jurídico italiano.

\section{Art. 57 (Revisión económico-financiera)}

1. Los Consejos municipales y provinciales elegirán, con voto limitado a dos miembros, un Colegio de Censores compuesto por tres miembros.

2. Los miembros del Colegio de Censores de cuentas deberán ser elegidos:

a) uno de entre los inscritos en el Registro de Censores Jurados de Cuentas, que actuará de Presidente.

b) uno de entre los inscritos en el Registro de Doctores mercantilistas;

c) uno de entre los inscritos en el Registro de Contables.

3. Su mandato durará tres años, no podrán ser destituidos, salvo incumplimiento, y serán reelegibles por una sola vez.

4. Los revisores tiene derecho a acceso a los acuerdos y documentos del ente.

5. El Colegio de Censores, de conformidad con el estatuto y con el reglamento, colaborará con el Consejo en su función de control y de dirección, ejerce la fiscalización sobre la regularidad contable y financiera de la gestión del ente y certifica la conformidad de la liquidación con las resultas de la gestión, redactando el oportuno informe, que se incorporará a la propuesta del acuerdo plenario de la liquidación del presupuesto.

6. En el mismo informe el Colegio formularán observaciones y propuestas tendentes a lograr una mejor eficiencia, productividad y economicidad de la gestión.

7. Los censores de cuentas responderán de la verdad de su certificación y cumplirán con sus deberes con la diligencia del mandatario. 
Darán cuenta inmediatamente al Consejo cuando encuentren graves irregularidades en la gestión del ente.

8. En los municipios con población inferior a 5.000 habitantes la revisión económico-financiera está atribuida a un solo censor electo por el Consejo municipal por mayoría absoluta de sus miembros y elegido entre expertos inscritos en los Registros a los que se refiere al párrafo 2, letras a), b) y c).

9. El estatuto podrá prever formas de control económico interno de la gestión.

\section{CAPITULO XV}

\section{RESPONSABILIDAD}

\section{Art. 58 (Disposiciones en materia de responsabilidad)}

1. Las disposiciones vigentes en materia de responsabilidad de los empleados civiles del Estado se aplicarán y al personal de los entes locales.

2. El tesorero y cualquier otro agente contable que haya manejado dinero público o esté encargado de la gestión de los bienes de los entes locales, así como aquéllos que se entrometan en el ejercicio de las funciones atribuidas a dichos agentes deberán rendir cuenta de su gestión y estarán sujetos a la jurisdicción del Tribunal de Cuentas según las normas y los procedimientos previstos por las leyes vigentes.

3. Los miembros del Comité Regional de Control responderán personal y solidariamente frente a los entes locales por los daños que le ocasionen por dolo o culpa grave en el ejercicio de sus funciones.

4. La acción de responsabilidad prescribe a los cinco años de la comisión del hecho. La responsabilidad respecto de las autoridades y de los empleados de los municipios y de las provincias será personal y no alcanza a los herederos.

\section{CAPITULO XVI}

\section{DISPOSICIONES FINALES Y TRANSITORIAS}

\section{Art. 59 (Plazos para la aprobación del estatuto)}

1. Los Consejos municipales y provinciales aprobarán el estatuto, el reglamento de contabilidad y el reglamento para la regulación de los contratos del ente en el plazo de un año desde la fecha de entrada en vigor de la presente ley. 
2. Hasta la entrada en vigor del estatuto, con limitación a las materias y regulaciones expresamente reservadas al mismo, continuarán aplicándose las normas vigentes en la fecha de entrada en vigor de la presente ley, en cuanto sean compatibles con ella.

3. Sin prejuicio de lo establecido en el párrafo 2 del presente artículo, hasta la entrada en vigor del estatuto, el número de consejeros queda fijado en la cantidad máxima prevista en el art. 33. Para la elección del Alcalde, del Presidente de la provincia y de la Junta se procederá según las modalidades provistas por el art. 34. Los plazos previstos en el párrafo 2 del art. 34, son la limitación a la Administración locales renovadas en las elecciones del 6-7 de mayo de 1990, se computarán desde la fecha de entrada en vigor de la presente ley.

4. En el Ministerio el Interior se creará un servicio para al recopilación y la conservación de los estatutos municipales y provinciales, que se encargará igualmente de las adecuadas mediada de publicidad de dichos estatutos.

5. Hasta la aprobación de la regulación del ordenamiento financiero y contable de los entes locales, continuarán aplicándose, en cuanto sean compatibles, las disposiciones vigentes en la fecha de entrada en vigor de la presente ley.

\section{Art. 60 (Revisión de los consorcios, de las asociaciones y de las circunscripciones)}

1. En el plazo de dos años desde la entrada en vigor de la presente ley, los municipios y las provincias procederán, aunque suponga la derogación de los límites de duración eventualmente previstos de los respectivos actos constitutivos, a la revisión de los consorcios $y$ de las otras formas asociativas existentes, constituidas entre los entes locales, suprimiéndolas o acomodándolas a las formas previstas por la presente ley.

2. Las circunscripciones creadas de acuerdo con la ley de 8 de abril de 1976, no 278, incompatibles con la nueva ordenación establecida por el art. 13, se entenderán prorrogadas hasta el primer cese de los Consejos municipales una vez que se haya aprobado el estatuto municipal.

\section{Art. 61 (Normas regionales en materia de organismos compren- soriales y asociativos, de comunidades de montaña y de órganos de control)}

1. En el plazo de dos años desde la fecha de entrada en vigor de la presente ley, las regiones adecuarán su legislación en materia de 
organismos comprensoriales y de formas asociativas entre los entes locales a los principios de la presente ley.

2. En el plazo de un año desde la fecha de entrada en vigor de la presente ley, las regiones reordenarán las comunidades de montaña según los criterios previstos en al art. 28, procediendo, igualmente, a la regulación de las relaciones existentes y las modalidades y tiempos de ejecución de dicha reordenación.

3. En el plazo de un año desde la fecha de entrada en vigor de la presente lay, las Regiones procederán a constituir los órganos de control de conformidad con las disposiciones contenidas en la presente ley, así como a la respectiva regulación legislativa regional.

4. El Capítulo III del Título V de la ley de 10 de febrero de 1953, no 62 , y posteriores modificaciones, tendrá eficacia hasta que las regiones hayan procedido al cumplimiento de lo previsto en el párrafo 3.

\section{Art. 62 (Delegación al Gobierno para la Región Valle de Aosta)}

1. Sin prejuicio de lo previsto en al art. 1, párrafo 2, se delega en el Gobierno la potestad de dictar para la Región de Valle de Aosta, en el plazo de dos años desde la fecha de entrada en vigor de la presente ley, mediante el procedimiento previsto en el art. 3 de la ley de 5 de agosto de 1981, no 453, uno o más Decretos que tendrán valor de ley ordinaria para armonizar las disposiciones de la presente ley con el ordenamiento de dicha región.

2. Las normas previstas en el párrafo 1 deberán tener cuenta de las particulares condiciones de autonomía atribuida a la Región.

\section{Art. 63 (Delegación al Gobierno para la primera revisión de las circunscripciones provinciales)}

1. Al objeto de la aplicación inicial del art. 16 y en la ejecución del art. 17, se delega en el Gobierno la potestad de dictar, en el plazo de dos años desde la entrada en vigor de la presente ley, uno o más decretos legislativos para la revisión de las circunscripciones provinciales y para la creación de nuevas provincias resultantes de la delimitación territorial de las áreas metropolitanas efectuadas por las Regiones.

2. Se delega al Gobierno, por el mismo plazo, la potestad de dictar decretos legislativos para crear nuevas provincias, que sean compatibles con lo dispuesto en el párrafo 1, para todas las áreas territoriales en las que, a 31 de diciembre de 1989, los municipios hayan puesto en marcha la iniciativa formal para crear nuevas provincias $y$ 
las Regiones hayan aprobado el informe favorable (Biella, Crotone, Lecco, Lodi, Prato, Rimini y Verbania) o se apruebe el informe favorable en el plazo de seis meses desde la entrada en vigor de la presente ley.

3. Los Decretos Legislativos de revisión de las circunscripciones provinciales y creación de nuevas provincias se dictarán, según lo dispuesto en el párrafo 1, con observancia de los principios y criterios directivos en al art. 16.

4. El Gobierno, recibidos los acuerdos e informes y comprobada la observancia de los requisitos exigidos por la presente ley, enviará los proyectos de Decretos a las regiones interesadas y a las Comisiones parlamentarias permanentes competentes que emitirán su informe en el plazo de los seis meses siguientes.

5. Los costes derivados de la aplicación de los párrafos precedentes, valorados en 3,5 miles de millones de liras para cada uno de los años 1990, 1991 y 1992, se cubrirán mediante la correspondiente reducción de la asignación inscrita, para el presupuesto trienal 19901992, en el capítulo 6856 del estado de previsión del Ministerio del Tesoro para el año 1990, utilizando para ello la rúbrica "Creación de nuevas provincias".

6. La autorización de gastos prevista en el párrafo 5 se consignará en el oportuno registro, en el que, según lo dispuesto en el art. 11, párrafo 3, letra d), de la ley de 5 de agosto de 1978, $n^{\circ} 468$, modificada por la ley de 23 de agosto de 1988, no 362, se cuantificarán en la ley de Presupuestos los gastos permanentes. Cualquier eventual aumento de gastos, respecto de la autorización prevista en el párrafo 5, deberá resultar cubierto.

\section{Art. 64 (Derogaciones de normas)}

1. Salvo lo previsto en el art. 59, párrafo 2, quedan derogadas:

a) el reglamento aprobado mediante Real Decreto de 12 de febrero de 1911, no 297, y sucesivas modificaciones y desarrollo, salvo los artículos 166 a 174 y 179 a 181;

b) el Texto Unico de la ley municipal y provincial aprobado mediante Real Decreto de 4 de febrero de 1915, no 148, y sucesivas modificaciones y desarrollos, salvo los artículos 125,127 , 289 y 190.

c) el Texto Unico de la ley municipal y provincial aprobado mediante Real Decreto de 3 de marzo de 1934, no 383 y sucesivas modificaciones y desarrollos, salvo los artículos $6 ; 18$, párrafo $1 ; 19 ; 20 ; 23$, párrafo $1 ; 24 ; 84 ; 87$, párrafo $1 ; 89 ; 96$; del 106 al $110 ; 140$, párrafo $1 ; 142$, párrafo $1 ; 147 ; 155 ; 279$; y con limita- 
ción a las funciones de la Comisión Central para las Haciendas Locales prevista por las leyes especiales, los artículos 328 al 331.

d) el párrafo 1 del art. 6 de la lay de 18 de marzo de 1968, no 444, entendiéndose atribuida a los municipios la competencia relativa a materia de construcción escolar.

2. Con efectos desde la entrada en vigor de la presente ley quedan derogadas cuantas disposiciones sean incompatibles con ella, salvo que en la misma se establezcan plazos distintos de vigencia.

3. En el plazo de seis meses desde la entrada en vigor de la presente ley, el Gobierno dictará un Texto Unico de todas las disposiciones vigentes en materia de ordenamiento de los entes locales.

\section{Art. 65 (Entrada en vigor de la ley)}

1. La presente ley entrará en vigor el día siguiente al de su publicación en la Gaceta Oficial de la República italiana.

La presente ley provista del sello del Estado, se incluirá en la Colección oficial de los actos normativos de la República italiana. A quien le corresponda queda obligado a observarla y a hacerla observar como ley del Estado.

Dada en Milán, el dia 8 de junio de 1990.

\section{COSSIGA}

ANDREOTTI, Presidente del Consejo de Ministros

GAVA, Ministro del Interior

Visto, el Guardasellos: VASSALLI 
